\title{
Neanderthal selective hunting of reindeer? The case study of Abri du Maras (south-eastern France)
}

Daujeard C. ${ }^{1, *}$, Vettese D. ${ }^{1}$, Britton K. ${ }^{2,3}$, Béarez P. ${ }^{4}$, Boulbes N. ${ }^{1}$, Crégut-Bonnoure E. ${ }^{5}$, Desclaux E. ${ }^{6}$, Lateur N. ${ }^{7}$, PikeTay A. ${ }^{8}$, Rivals F. ${ }^{9,10,11}$, Allué E. ${ }^{9,10}$, Chacón M.G. ${ }^{9,10,1}$, Courty M.-A. ${ }^{12}$, Gallotti R. ${ }^{13}$, Hardy B. ${ }^{14}$, Puaud S. ${ }^{1}$, Moncel M.-H. ${ }^{1}$

${ }^{1}$ Histoire Naturelle de l'Homme Préhistorique (HNHP, UMR 7194), Sorbonne Universités, Muséum national d'Histoire naturelle (MNHN), CNRS, Université de Perpignan Via Domitia, Institut de Paléontologie Humaine, 1 rue René Panhard, 75013 Paris, France

${ }^{2}$ Department of Human Evolution, Max Planck Institute for Evolutionary Anthropology, Deutscher Platz 6, 04103 Leipzig, Germany

${ }^{3}$ Department of Archaeology, University of Aberdeen, St. Mary’s Building, Elphinstone Road, Aberdeen, Scotland, United Kingdom AB24 3UF

${ }^{4}$ Archéozoologie, archéobotanique : sociétés, pratiques et environnements (UMR 7209), Sorbonne Universités, MNHN, CNRS, 55 rue Buffon, CP 56, 75005 Paris, France

${ }^{5}$ Museum Requien, 67 rue Joseph Vernet, 84000 Avignon, France

${ }^{6}$ Laboratoire départemental de Préhistoire du Lazaret (UMR 7194-USM 204), 33 bis boulevard Franck Pilatte, 06300 Nice, France

${ }^{7}$ Laboratoire Méditerranéen de Préhistoire Europe Afrique (LAMPEA, UMR 7269), Maison Méditerranéenne des Sciences de l'Homme, BP 647, 13094 Aix-en-Provence cedex 02, France

${ }^{8}$ Department of Anthropology, Vassar College Raymond Ave., Poughkeepsie, NY 12604

${ }^{9}$ Institut Català de Paleoecologia Humana i Evolució Social (IPHES), Zona Educacional 4, Campus Sescelades URV (Edifici W3), 43007 Tarragona, Spain

${ }^{10}$ Àrea de Prehistòria, Universitat Rovira i Virgili (URV), Av. Catalunya 35, 43002 Tarragona, Spain

${ }^{11}$ Institució Catalana de Recerca i Estudis Avançats (ICREA), Pg. Lluís Companys 23, 08010 Barcelona, Spain

${ }^{12}$ Laboratoire PROMES - Procédés Matériaux et Energie Solaires (CNRS-UPR 8521), Rambla de la Thermodynamique, Tecnosud, 66100 Perpignan, France

${ }^{13}$ Dipartimento di Scienze dell'Antichità, Università di Roma La Sapienza, Via dei Volsci 122, 00185 Roma, Italy

${ }^{14}$ Department of Anthropology, Kenyon College, Gambier, OH 43022, USA

* Corresponding author. E-mail address: camille.daujeard@mnhn.fr

\section{Keywords}

Neanderthal; Subsistence; Seasonality; Monospecific faunal assemblages; Reindeer predation; Mass procurement

\begin{abstract}
Monospecific exploitation of reindeer by Neanderthals is common behaviour in the Upper Pleistocene of Western Europe. However, reindeer-dominated assemblages have largely been reported from regions of northern Germany and south-western France, with few examples noted in south-eastern France, where faunal assemblages are most of the time dominated by a variety of other large ungulates such as red deer, horse and diverse bovids. Here, we present multi-
\end{abstract}


strand (bio- and eco-) archaeological datasets from the site of Abri du Maras (level 4.1), situated at the mouth of the Ardèche and Rhône rivers, a new example of a reindeer-dominated Neanderthal site in south-eastern France. Dated to the beginning of the MIS 3, the zooarchaeological assemblage is dominated by reindeer (88\% of the NISP, representing 16 individuals), but also includes horse, bison, megaceros, red deer, ibex and lagomorphs. The combination of zooarchaeological, cementochronological and tooth microwear analyses evidence a single-species dominated spectrum, with catastrophic mortality and repeated autumnal deaths. This integrated approach provides an extensive picture of human subsistence behaviour, pointing to short-term hunting episodes of reindeer herds in an exceptional context of a quasi-exclusive Neanderthal accumulation. The high number of individuals and selective butchery may correspond with a cooperative and planned mass hunting strategy. The multidisciplinary approach undertaken here also incorporating paleontological, charcoal, ecological, and isotopic analyses places the archaeological and zooarchaeological data within a broader regional palaeoenvironmental framework, providing valuable landscape-contextual information. The zooarchaeological data suggest a subsistence behaviour different from other Neanderthal reindeer-dominated assemblages often connected with specialised butchery or hunting sites.

\section{Introduction}

The hunting abilities of Neanderthals are now well documented, not least due to the many debates at the end of the $20^{\text {th }}$ century concerning the recognition of human versus carnivore faunal accumulations and the question of hunting versus scavenging in Middle Palaeolithic occupations (e.g. Binford 1981, 1988; Chase 1986; Stiner 1994; Marean 1998; PatouMathis 1997). More recently, other important advances have been made in archaeological research and associated fields, which not only demonstrate the proficiency of Neanderthal (and their predecessors) hunting, and have also revealed further similarities, and a far closer relationship, to modern humans than previously thought. For example, recent advances in genomic research have now demonstrated direct interaction between modern humans and Neanderthals through interbreeding (Green et al. 2010; Fu et al. 2015). The decreasing gap in the perceived biological distance between modern humans and Neanderthals is mirrored by archaeological research, as the behavioural juxtapositioning of 'Humans vs. Neanderthals' is increasingly called into question. In the field of subsistence and game exploitation, new evidence of hunting weapons discovered at Schöningen (Thieme 1997; Schoch et al., 2015), combined with many archaeozoological studies (e.g. Gaudzinski-Windheuser 1996; Patou-Mathis 2000), have highlighted specialized Neanderthal predation of medium and large-sized ungulates, and archaeozoological and isotopic studies have evidenced targeted interception hunting (e.g. Gaudzinski and Roebroeks 2000; Britton et al. 2011; Julien et al. 2015; Kuitems et al. 2015; Rivals et al. 2015).

Single-taxa assemblagesare significant as the tactic of specialized and mass hunting involves planning and collaborative behaviours. This is particularly the case when assemblages are the result of focused temporally constrained hunting activities, where resources are seasonally restricted (e.g. due to their migratory behaviour) or where the condition of prey-species is highly seasonally varied (for example, in reindeer). Often species targeted are gregarious, and would have been intercepted by humans at places attracting the aggregation of many individuals, for example, at water sources, or more seasonally at calving grounds, during the rut, or along migratory corridors. Monospecific assemblages that are rapidly accumulated such as single mortality events are also significant in that they suggest mass food procurement, and through this imply the planning of carcasses processing and the storage and transport of meat and marrow for deferred consumption (David and Enloe 1993; Costamagno 2006; Gaudzinski-Windheuser and Kindler 2012; Rendu et al. 2012). In this sense, monospecific assemblages, imply advanced planning and cooperative hunting behaviours, and an in-depth knowledge of prey and landscape. 
Monospecific faunal assemblages appear from stages 9 to 7 with pre-Neanderthals and become more common from the beginning of the Last Glacial period to the end of the Middle Palaeolithic (Gaudzinski 1996; Patou-Mathis 2000; Gaudzinski-Windheuser 2006; Gaudzinski-Windheuser and Kindler 2012), without any specific increase during the Upper Palaeolithic (Grayson and Delpech 2002, 2003; Kitagawa et al. 2012). Indeed, many pre-Neanderthal and Neanderthal sites in Europe and in the Middle East highlight specialized hunting for a wide variety of middle-sized or large-sized ungulates: reindeer at Salzgitter-Lebenstedt, Les Pradelles and Jonzac (Gaudzinski and Roebroeks 2000; Costamagno et al. 2006; Airvaux 2004; Niven et al. 2012); camel at Umm El Tlel (Boëda et al. 2001); aurochs and/or bison at La Borde, Mauran, Wallertheim and II'skaja I (Jaubert et al. 1990; Farizy et al. 1994; Gaudzinski 1995; Hoffecker, Baryshnikov and Potapova 1991); red deer at Saint-Marcel and Le Lazaret (Daujeard 2007, 2008; Valensi et al. 2013); horse at Orgnac 3, Zwolen, Kabazi II and Starosele (Gautier 1989; Patou-Mathis 1999; Burke 2000, 2006; Moncel et al. 2012); or small bovids, ibex or chamois at Scladina (Patou-Mathis 1998), Baume des Peyrards (Daujeard 2008), Zafarraya (Caparros et al. 2012) and in the numerous Middle Palaeolithic sites of the Pyrenean, Alpine, Cantabrian and Caucasus mountains (e.g. Patou-Mathis 2000; Yravedra and Cobo-Sanchez 2015). Monospecific assemblages at Neanderthal sites often share common characteristics. For example: accumulation via regular short events; the predominance of remains of a single species (and many individuals) associated with lithic artefacts and cutmarks; catastrophic mortality profiles; and selective transport of carcass portions from the kill site to the base camp (Gaudzinski-Windheuser 2006; Costamagno et al. 2006; Gaudzinski-Windheuser and Kindler 2012; Rendu et al. 2012). In light of cross-site similarities, ungulate mass procurement hypothesis is often confirmed or refuted through a similar compilation of multiple zooarchaeological lines of evidence, e.g. threshold number of prey bones, mortality caused by humans, single depositional episode and single mortality event (Lubinski 2013). However, the assessment of monospecific (and other) faunal assemblages, and their interpretation, is blighted by the problem of equifinality in accumulations resulting from combined carnivore and anthropogenic action (Rogers 2000; Lyman 2004). Despite huge progress in the recognition of the various agents of accumulation over the last decades (mainly thanks to archaeological and experimental data on bone surface modifications; age and skeletal profiles or faunal spectra: Cruz-Uribe 1991; Blumenschine et al. 1996; Blumenshine and Selvaggio 1998; Pickering 2002; Guadelli 2008; etc.), exclusively human accumulations still represent the best contexts to study human behaviours.

Unfortunately, such sites remain rare in the Middle Palaeolithic, but are vital for confidently inferring past behaviours. Here, we present new zooarchaeological, archaeological, paleontological and isotopic data from the Middle Palaeolithic site of Abri du Maras, Ardèche, in Southeast France. The site was first excavated by R. Gilles and J. Combier during the second half of the $20^{\text {th }}$ Century and research was resumed at the site in 2010 by one of the authors (M.-H. Moncel). Abri du Maras is now the focus of a major multi-disciplinary archaeological investigation. This vast rock shelter is situated along the right blank of the Middle Rhône Valley, at the confluence with the Ardèche River and features several wellpreserved levels of occupation dated to the first half of the Last Glacial period (MIS 4-3) (Moncel and Michel 2000; Richard et al. 2015). Abri du Maras comprises an extensive assemblage of anthropogenically-modified animal bones associated with Middle Palaeolithic lithic artefacts, with very few carnivore remains and little evidence of carnivore activity. Due to the excellent spatial preservation of level 4.1, which is dominated by reindeer, and the likelihood that Neanderthals were practically the sole accumulators, this phase of the site is ideal for furthering our understanding of Middle Palaeolithic monospecific and mass faunal assemblages, and therefore, for elucidating Neanderthal landscape use, hunting practices, and social behaviours.

\section{Abri du Maras}




\section{Geographical setting}

The site of Abri du Maras (170 m a.s.l.) is situated on the right blank of the Middle Rhône Valley, in a small dry valley of the Ardèche River, at the outer edge of the gorges (Fig. 1). It is perched $70 \mathrm{~m}$ above the river, and is all that remains of a huge, former south-east facing rock shelter. This rock shelter is the relict of successive phases of tectonic activity, dissolution and erosion processes that contributed to exposing and altering a pre-Quaternary karst network. The presence of large limestone slabs throughout the sequence evidences the vaster expanse of the shelter at the time of occupation and also to its final collapse soon after the last occupation (Debard 1988; Moncel et al. 2010, 2015).

\section{Figure 1.}

The Rhône Valley comprises notable archaeological and topographical features: a vast corridor linking the North of Europe to the Mediterranean zone, and a key position between two mountainous regions - the Massif Central to the west and the Alpine foothills to the east. Many East-West tributaries on the right bank of the Rhône River connect the Rhône Valley to the plateaus of the Massif Central. In this region, previous studies of Neanderthal subsistence suggested a probable seasonal model, based on the presence of sites with different occupation types. Evidence of settlement in caves and rock shelters clustered around the Ardèche gorges results from the seasonal activities of larger groups, focusing on monospecific prey, while the occasional bivouac occupations of other sites are more likely to represent opportunistic faunal exploitation alternating, for example, with carnivore visits (Daujeard 2008; Daujeard and Moncel 2010; Moncel and Daujeard 2012; Daujeard et al. 2012).

\section{Stratigraphy and dating}

The first archaeological investigations at Abri du Maras revealed a stratigraphic sequence of about $3 \mathrm{~m}$ including eight levels with Middle Palaeolithic deposits. This site was renowned in the past for its Middle Palaeolithic (MP) deposit with a Levallois laminar debitage (level 1) (Gilles 1950; Combier 1967; Debard 1988; Moncel et al. 1994). The new excavation only concerns the middle and lower parts of the sequence, from previously assigned levels 4 to 8 . The stratigraphic unit 5 (levels 8-6 of earlier excavations) is at present the oldest currently known unit and lies abruptly on the erosional contact of the limestone substratum at the back of the shelter. The overlying unit 4 (this study, has been extensively exposed across the rock shelter and consists of a silt and sandy-silty sedimentary accumulation $(0.5$ to $1 \mathrm{~m}$ thick). The coarse fraction results from frost shattering the walls of the rock shelter. The fine fraction can be assigned to loess-like deposits of aeolian origin (Antoine 2002), on the basis of sedimentological data (Figs. S1a-b). The mineralogy (Nowak 2013; Puaud et al. 2015) indicates that the deposit appears to have mostly originated from the wind erosion of the fluvio-glacial terraces of the Middle Rhône valley during the cold and dry conditions of MIS 3. Micromorphological features (Fig. S1c) show that the entire unit 4 appears to have been affected by moderate pedological evolution, mostly expressed by earthworm bioturbation and the biogenic redistribution of calcium carbonate (Brochier 1976; Jaillard et al. 1991; Canti 1998; Kooistra and Pulleman 2010).

Unit 4 contains in its upper part two archaeological levels, 4.2 and 4.1 (Fig. 2). The excavation showed that these two levels (previously 5 and 4) correspond respectively to two well-preserved human occupation phases marked by abundant artefacts with scant traces of combustion and occasional diffuse ash lenses. Unit 4 is currently excavated over an area of more than $50 \mathrm{~m}^{2}$, in the front of the remaining shelter (Moncel et al. 2014). Finally, only scattered and rare 
artefacts have been encountered in the overlying units $(3,2$, and 1), which contrast with unit 4 by their coarse texture and the abundance of large blocks.

\section{Figure 2.}

U/Th dating applied to bones from the top of unit 5/bottom of unit 4 yielded ages of $72 \pm 3 \mathrm{ka}, 87 \pm 5 \mathrm{ky}, 89 \pm 4 \mathrm{ky}$, and $91 \pm 4$ ky (Moncel et al. 1994; Moncel and Michel 2000). New preliminary ESR-U/Th dating of ungulate teeth confirmed the chronology of unit 5 ( $90 \pm 9 \mathrm{ky}$ ) but gave more recent ages for unit 4, attributed to MIS 3. Level 4.1 (upper part of unit 4) thus dates to between $40 \pm 3 \mathrm{ky}$ and $46 \pm 3 \mathrm{ky}(n=2)$ (also MIS 3), while samples from level 4.2 provided ages ranging from $42 \pm 3 \mathrm{ky}$ to $55 \pm 2 \mathrm{ky}$ ( $n=3$ ) (MIS 3) (Richard et al. 2015).

\section{Archaeology and environment}

The close association of archaeological materials with coarse fraction issued from the pedogenic alteration of the limestone cliff together with collapsed limestone slabs in the two occupation levels (levels 4.1 and 4.2) of unit 4 enables us to establish strict synchrony between human presence and climatic conditions characterized by seasonal moisture and mild temperatures. In contrast, the fine silt texture typical of aeolian dust, the weak effect of pedogenesis and the lack of coarse limestone fraction in the sterile level deposited between levels 4.1 and 4.2 indicate that the site was not occupied when the climate was colder and drier. Microfauna, charcoal and pollen are very rare at the site due to poor preservation. Previous faunal studies highlighted the presence of temperate species such as red deer, roe deer and wild boar in unit 5, whereas cold and open environment species such as reindeer, horse and bison are more common in unit 4 and in the overlying units. The varied faunal spectrum previously obtained for the unit 4 is composed, in order of abundance, of Rangifer tarandus, Equus ferus cf. germanicus, Cervus elaphus, Bison priscus, Capra ibex, Equus hydruntinus and Megaloceros giganteus. All along the sequence, faunal remains are mainly related to anthropogenic activities and carnivore marks are scarce (Moncel et al. 1994; Daujeard 2008; Daujeard and Moncel 2010; Moncel et al. 2015).

In this paper, we focus on level 4.1, the uppermost occupation unit 4, due to the lack of carnivore action, remarkable spatial preservation with short object displacements, technological behaviour based on similar strategies suggesting occupations close in time and the presence of ash lenses. Level 4.1 has been exposed over a surface of $34 \mathrm{~m}^{2}$. The excavation revealed a dense accumulation of archaeological remains reaching a total thickness of $20 \mathrm{~cm}$. However, the clayey-sandy silt sedimentary matrix of level 4.1 is homogenous throughout and does not display any significant change in colour, structure or texture, in close association with the occurrence of the archaeological remains. Based on the lack of field evidence, it was presumed that archaeological level 4.1 did not present well-preserved living floors. However, the meticulous excavation of this level revealed the scattered occurrence of fire traces, mostly represented by poorly preserved mm-sized charcoal fragments which are finely incorporated in the matrix. Burnt flint and burnt bone also provide evidence of the use of fire and are dispersed over the archaeological level. In addition, occasional $\mathrm{cm}$-sized lenses formed of dark-brown to brownish-grey silty clay, consisting of densely packed biogenic aggregates with high quantities of fine charcoal, ash micro-aggregates, burnt bones and polymer films occur throughout level 4.1. Based on their field facies and the abundance of combustion residues, the lenses have been assumed to be relicts of fire-related activities. They are all located at a same deepness, suggesting a main phase of occupation. An important number of faunal and lithic refits have been identified in level 4.1 (Fig. 3). In the case of the faunal assemblage, the total number of refits is 65 ( $n=44$ on fresh and 21 on dry bones) connecting 148 items. The longest refit is formed by eight elements 
$(n=1)$ but the majority have only two elements $(n=51)$. In addition, 22 faunal anatomical connections, grouping 68 bones, were also identified. There are also 10 lithic refits comprising a total of 20 pieces (mainly flakes and all formed by two elements). The raw materials involved are flint $(n=7)$ and quartz $(n=3)$. The connection lines are mainly related to knapping sequences $(n=6)$ although some are the result of fractures (during knapping $n=2$ and post-depositional $n=2$ ). The fact that faunal and lithic connections lines are short (mean of $1.5 \mathrm{~m}$ ) and some of the connected items are small $(\leq 1.5 \mathrm{~mm})$, corroborates the low level of disturbance of the archaeological assemblage from level 4.1.

\section{Figure 3.}

The lithic material in level 4.1 totals 1844 items. The density is 135 pieces $/ \mathrm{m}^{2}$ and $54 / \mathrm{m}^{3}$. Lithic analysis, undertaken by several of the authors, revealed that the technical strategies applied mainly to flint and secondarily to other stones (quartz, quartzite and granite) indicate the fragmentation of reduction processes into local and semi-local perimeters around the site (Moncel et al. 2014). The main core technology is Levallois, generally on cortical flint cores on flakes. Flint flakes, blades and points are the main components of the series and the technological aims of the debitage. The largest flint flakes, Levallois blades (cortical or not) and Levallois points were produced elsewhere, to the north and south of the site (up to $20-30 \mathrm{~km}$ ), according to the geological study, and then brought to the shelter. Flake-tools are very rare (3\%), and never modified the shape of the pieces. Levallois products were never retouched. We may mention one Quina scraper made on a thick and large flint flake. Evidence of impact fractures suggests that some points, brought to or prepared on the site, could have been used as projectile tips (Hardy et al. 2013). The lithics attest to the management of local and semi-local stones in a perimeter of $30 \mathrm{~km}$ around the site (possibly more due to some unidentified flint) and an anticipation of domestic needs. Imported artefacts and artefacts made on the site were used for the same range of activities and materials (butchery, plant and woodworking). Neanderthals exploited a wide range of resources including large mammals, fish, ducks, raptors, rabbits, mushrooms, plants, and wood. Twisted fibres on stone tools provide possible evidence of making string or cordage (Hardy et al. 2013).

\section{Material and Methods}

The faunal material included in this study comes exclusively from archaeological find level 4.1 from Abri du Maras. The analysis of the faunal assemblage features a range of scientific approaches and methodologies including taphonomic and zooarchaeological analysis in order to explore the species present, age-at-death (where possible), and infer anthropogenic modifications and other taphonomic features; cementochronology to infer season-of-death; stable isotope and dental microwear analysis to explore the niche feeding behaviours of the exploited species, and palaeoenvironmental proxies (faunal and charcoal) in order to gain better insight into the MIS 3 ecosystem surrounding Abri du Maras.

\section{Taphonomy and zooarchaeology}

The taphonomic and zooarchaeological studies concern all the faunal remains from level 4.1 since the 2006 excavations. We report the total number of skeletal remains (NR), the number of taxonomically and anatomically identified specimens (NISPt and NISPa), the minimum number of elements (MNE) and the minimum number of individuals (MNI) (Binford 1984; Lyman 1994). In level 4.1, small and large mammals represent 11,123 remains including indeterminate remains (Table 1). The number of coordinated remains is 2,919 and 1,347 remains have been 
identified to the anatomical level and 1,170 to the species level. Fish remains account for 167 bone elements, birds are represented by two remains and we recorded five micromammal anatomical elements. Systematic sieving was

\section{Table 1.}

In order to discuss the meat procurement strategy (hunting or scavenging), selective carcass transport to the site and differential bone preservation, we used the percentage of Minimal Animal Unit (MAU, Binford 1984), the Food Utility Index (FUI) (Metcalfe and Jones 1998; Lyman 1994), the volume of the marrow cavity (Binford 1978, in Jones and Metcalfe 1988) and the bone bulk density (Lyman 1984; Lam et al. 1999). Carcasses were divided in seven main anatomical parts: head (skull, mandibles, isolated teeth excepted); axial elements (vertebrae, ribs, sternum); forequarters (scapula, humerus, radio-ulna); forefoot (carpal, metacarpal); hindquarters (pelvis, sacrum, femur, tibia, patella); hindfoot (tarsal, metatarsal); indeterminate foot (phalanges, sesamoids, metapodials) (after Wilson 1989, modified). Seasonality and ontogenic age-at-death of prey specimens is based on dental eruption and replacement patterns (for deciduous teeth concerning the season of death) and then on tooth-wear (wear stages for reindeer: cf. Bouchud, 1966 and Miller, 1974; for red deer and by analogy megaceros: Riglet 1977; for bison: Brugal and David 1993 and for horses: Guadelli 1998; Forsten and Moigne 1998 or Bignon 2003). Five main age groups were established: juveniles (with deciduous teeth), young adults (with erupted P4 and M3), prime-age adults (with moderately worn P4 and M3), old adults (with heavily worn P4 and M3) and senile (almost no enamel remains on P4 and M3) (Grant 1982; Klein and Cruz-Uribe 1984; Forsten and Moigne 1998). For reindeer, these five age classes represent nearly the same lifetime with juveniles ranging from 0 to 2.5 years old; young adults: 2.5 to 5 ; prime-age adults: 5 to 7.5 ; old adults: 7.5 to 10 and senile: up to 10 years old. In order to use ternary diagrams established by Stiner (1990), the three age categories were corrected - juveniles $(<2.5)$, adults $(2.5$ to 10$)$ and old individuals $(>10)$ - according to their relative lifespans. For larger ungulates, such as bison and horse, the adult category begins later, with the loss of the D4 and the eruption of the P4 and M3, at about 40-50 months old.

For comparative purposes for large mammal representation, richness and diversity indexes were calculated (Simpson 1949; Magurran 1988; Grayson and Delpech 2002; Valensi et al. 2013): 1) The taxonomic richness: $R=S-1$ / Ln MNI (with $\mathrm{S}=$ number of species and $\mathrm{MNI}=$ total minimum number of individuals); 2) the Simpson index: $D=\sum n i[n i-1] / N[N-1]$ (with $n i=$ the number of specimens for each species and $N=$ the total number of specimens); 3) The Shannon diversity: $\mathrm{H}=-\sum[(M N I s p / M N I t o t) \log 2(M N I s p / M N I t o t)]$ (with MNIsp = minimum number of individuals for each taxon and MNItot = total minimum number of individuals $)$ or $\mathrm{H}=-\sum[(N I S P s p /$ NISPtot) $\log 2($ NISPsp /NISPtot)] (with NISPsp = number of identified specimens for each taxon and NISPtot = total number of identified specimens) and 4) The Equitability index or Evenness is obtained by the Shannon index/Ln (n taxa).

For the taphonomic analysis, the dimensions (length, breadth and thickness) and modification data were recorded for all the coordinated and identified specimens. Indeterminate fragments less than $25 \mathrm{~mm}$ were only used for counts, fragmentation studies (type and size classes) and carbonization analyses. The identification of the type of breakage (green, dry or recent bone fractures) was made based on the fracture colour, shape, feature and angle and associated marks (Villa and Mahieu 1991). The recorded percussion marks are (Blumenschine and Selvaggio 1988; Capaldo and Blumenschine 1994; Blasco et al. 2013): medullary or cortical percussion notches (negative flake scars); impact flakes (positive flake scars); percussion pits; adhering flakes; peeling and micro-notches (Vettese 2014). The shaft fragments were differentiated by size and circumference classes (cf. Villa and Mahieu 1991). For indeterminate fragments, two 
main size categories were established, adapted to the ungulates present in our sample: (1) medium-sized ungulates with a weight between 50 and $300 \mathrm{~kg}$ (red deer, reindeer and ibex) and (2) large-sized ungulates with a weight between 300 and $1000 \mathrm{~kg}$ (large bovids, horse and megaceros).

All bone surfaces were visually assessed, with some studied further using a stereomicroscope (Leica S8 APO, magnification 10-80x) in order to distinguish surface modifications, and photographed. Type and location of modifications were recorded, including those made by rodents, carnivores or hominins as well as climatic and edaphic modifications (including cracking, desquamation, polish, concretion, root marking, chemical corrosion and oxides coloration). The identification of these main taphonomical modifications was based on the criteria defined by Behrensmeyer (1978), Binford (1981), Lyman (1994) and Fisher (1995). The illegible remains were not included in the percentages. Trampling marks were distinguished from butchering marks using the works of Binford (1981), Shipman and Rose (1983, 1984), Behrensmeyer et al. (1986), Olsen and Shipman (1988), Blasco et al. (2008) and DominguezRodrigo et al. (2009). The location and morphology of the latter may indicate the related butchering activity, including evisceration; skinning; dismemberment; disarticulation; periosteum removal; cutting tendons and defleshing (Binford 1981; Nilssen 2000; Pobiner et al. 2008; Costamagno and David 2009). Following Binford (1981), Haynes (1983) and Campmas and Beauval (2008), carnivore marks were classified as follow: pits, punctures, scores, notches or corrosion by gastric acids. Damage due to burning was recorded using the different colour stages described by Stiner et al. (1995) (Table S1). In addition, burnt elements were categorized according to their length and intrinsic characteristics: spongious, compact or dental portions.

Isotopic studies: Methods and material

As part of a broader multi-isotope study incorporating faunal bones and teeth from multiple archaeological find levels at Abri du Maras, a small number of bones $(n=9)$ from three different taxa (Equus, Megaloceros, Rangifer) were selected from level 4.1 for collagen extraction, and carbon $\left(\delta^{13} \mathrm{C}\right)$ and nitrogen $\left(\delta^{15} \mathrm{~N}\right)$ isotope analysis. The stable isotope analysis of bone collagen is not only useful in archaeological studies to infer human palaeodiet, but can also provide information about the broader environment, and also about niche partitioning and feeding behaviours of different herbivore taxa, even within purely-C3 plant communities (e.g. Bocherens 2003; Feranec 2007). For example, the consumption of lichens, which exhibit higher $\delta^{13} \mathrm{C}$ values than other terrestrial C3 plants (Ben-David et al. 2011; Drucker et al. 2001, 2012), or feeding in forested environments, which typically have more negative $\delta^{13} \mathrm{C}$ values due to the 'canopy effect' (Cerling et al. 2004; Noe-Nygaard et al. 2005). Although they are on the same trophic level, absolute $\delta^{15} \mathrm{~N}$ values of herbivore tissues depend on a number of factors, and in particular on the varying ${ }^{15} \mathrm{~N}$ levels of the plants they consume (and ultimately the soils) at the base of the food chain. For a recent review of the factors influencing nitrogen isotope ratios in plants, including plant physiology, see Szpak (2014). Therefore, given that local variation in soil and plant $\delta^{13} \mathrm{C}$ and $\delta^{15} \mathrm{~N}$ isotope composition is reflected in local herbivores, the stable isotope analysis of animal bone collagen can be used to investigate resource partitioning and underlying isotopic variations in ancient ecosystems (Britton et al. 2012). Moreover, the absolute $\delta^{13} \mathrm{C}$ and $\delta^{15} \mathrm{~N}$ determined in herbivore bone collagen at archaeological sites can also be utilised to infer broad palaeoclimatic conditions (e.g. Richards and Hedges 2003; Stevens and Hedges 2004; Stevens et al. 2008). This is due to the relationship between 'baseline' ecosystem $\delta^{13} \mathrm{C}$ and $\delta^{15} \mathrm{~N}$ values of soils and plants, and changing diachronic environmental factors such as aridity/moisture and temperature (e.g. Heaton et al. 1986; Schwarcz et al. 1999; van Klinken et al. 2000). In this way, overall dataset values and trends (between the different herbivore species) can shed light on the palaeoenvironmental and palaeoecological conditions at Abri du Maras. 
Herbivore bone $(\approx 1-2 \mathrm{~g})$ was sampled for collagen extraction using rotary stainless steel cutting implements and cleaned using air abrasion. Collagen was extracted using the Longin method (1971), with modifications based on the recommendations of Collins and Galley (1998), and with the addition of an ultrafiltration step (Brown, et al., 1988), as described in Britton et al. (2012). Collagen samples were analysed (in duplicate) for stable carbon $\left(\delta^{13} \mathrm{C}\right)$ and nitrogen $\left(\delta^{15} \mathrm{~N}\right)$ isotope ratios at the Department of Human Evolution, Max Planck Institute for Evolutionary Anthropology (MPI-EVA, Leipzig, Germany), on a Delta XP mass spectrometer coupled to a Flash EA 2112 elemental analyser.

\section{Dental microwear analysis: Methods and material}

Microwear features of dental enamel were examined using a stereomicroscope on high-resolution epoxy casts of teeth following the protocol developed by Solounias and Semprebon (2002). After cleaning, the occlusal surface of the teeth was moulded using high-resolution silicone (vinylpolysiloxane) and casts were created using clear epoxy resin. Casts were observed under incident light with a Zeiss Stemi 2000C stereomicroscope at 35× magnification, using the refractive properties of the transparent cast to reveal microfeatures on the enamel. We used the classification of features defined by Solounias and Semprebon (2002) and Semprebon et al. (2004) and quantified all categories of microwear features (pits and scratches) on the paracone of the upper molars or the protoconid of the lower molars in a standard square area of $0.16 \mathrm{~mm} 2$ using an ocular reticule. Two areas were analysed on each tooth and the results were averaged. We report the average numbers of pits and scratches, as well as a dietary indicator (\%0-17, following Semprebon and Rivals 2007). Finally, following Rivals et al. (2015), two measurements of variability of scratch density, namely the standard deviation (SD) and the coefficient of variation (CV) are used to estimate the duration of the "mortality event" of the reindeer from Abri du Maras level 4.1.

\section{Cementochronology: Methods and material}

Multiple teeth from nine deer including one megaceros and eight reindeer from level 4.1 were selected as these appeared to the naked eye to have intact outer dental cementum. The methodology employed here for dental cementum growth mark analysis (cementochronology) of the cervid teeth follows the protocol described in Pike-Tay (1995), which built upon the methodological contributions of Pike-Tay (1991), Lieberman et al. (1990), and Burke (1993), including:

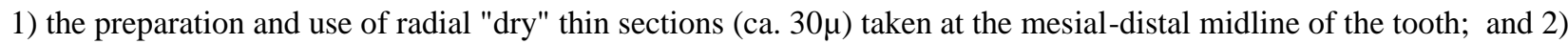
the use of polarized transmitted light (common mag. $=40 \mathrm{x}, 100 \mathrm{x}, 250 \mathrm{x}$ ) 3) for taking measurements of consecutive growth zone widths at 2 or 3 cementum transects per tooth in the areas of acellular cementum near the tooth cervix (root/enamel junction) where, on cervid and bovid teeth the apposition of growth increments is most regular.

\section{Results and data interpretation}

\section{Bone preservation}

The identification index, defined as the number of anatomical identified remains compared to the total number of remains, is around $12 \%$, which is low and mainly due to the high fragmentation of the fauna (Table 1; Fig. S2). Indeed, the faunal assemblage is characterized by an important quantity of bone fragments, which are mainly unidentified bone splinters and by a few isolated teeth (Table 1). Almost three-quarters of the recorded bone remains have one or several green bone fractures (Table S2). Fracture profiles are mainly curved/V-shaped along with oblique angles and smooth 
edges (Fig. 4). Post-depositional fragmentation due to sediment compaction or secondary frost action damaged more than one third of the recorded remains. Only five complete or almost complete long bones were recorded. They are all metapodials: one horse metacarpal (III), three reindeer metacarpals and one reindeer metatarsal. Shaft bone fragments are far more numerous than epipyhseal fragments (Fig. S3). The vast majority (89\%) have been reduced to a C1 circumference and have a L1/L2 length (Fig. S4).

\section{Figure 4.}

To evaluate the impact of bone preservation on the assemblage, we correlated bone density indexes with the \% MAU for reindeer remains, which is the predominant species. The significantly positive correlation obtained between \%MAU and bone density (with Spearman's $r s=0.65, \mathrm{df}=29$ and $\mathrm{t}=4.67: \mathrm{p}<0.001$ ) indicates strong differential destruction within the faunal assemblage. However, bone preservation is variable, depending on the excavated surface areas of the rock shelter. Some display an excellent degree of preservation and others show a high bone destruction index. In general, the bone destruction index, calculated as the number of isolated teeth compared to the total number of anatomically identified remains, is around $17 \%$, which is moderate, but this rate may also be due to a strategy of abandonment of the heads at the kill site (see below) (Table 1). The representation of the various long bone portions confirms the impact of differential bone destruction on the sample (Fig. S3). Indeed, the best represented extremities are those with greater bone density, i.e. metapodials, radius-ulna and distal humerus (see Lam et al. 1999). The good preservation of some articular portions can be explained by the almost complete lack of carnivorous action. Only 10 bone elements bear carnivore marks, which represents less than $1 \%$ of the coordinated and legible remains. These are long bone articular portions of horse and reindeer and a few indeterminate remains. Besides that, there are also a very few remains $(\mathrm{NR}=7$; $<1 \%$ ) with random striations on their surface which can be associated with trampling.

Remains with illegible surfaces are numerous, representing one third of the coordinated remains (Table 1). They have been excluded from the cut-mark or bone retoucher analyses in order to avoid biasing the calculation of the rates. This illegibility is mainly due to root etching which is present on almost $90 \%$ of the coordinated bone remains, with more than $50 \%$ being invasive on two-thirds of the surfaces (Table S3). Evidence of weathering is scant and concretions and polishing are practically inexistent. Black and orange colorations (oxides) are omnipresent but limited over bone surfaces (mostly stage 1).

\section{Palaeoenvironments: the faunal, isotopic and charcoal evidence}

Among small and large mammal remains, $98.7 \%$ of the NISPt are ungulates and $1.3 \%$ are lagomorphs. There are no carnivore remains. They include, in order of abundance (Table 2): reindeer (Rangifer tarandus), horse (Equus ferus cf. germanicus), megaceros (Megaloceros giganteus), bison (Bison priscus), red deer (Cervus elaphus), ibex (Capra ibex) and lagomorphs (Oryctolagus cuniculus and Lepus sp.). This diversity confirms previous studies of level 4, highlighting open landscapes and a cold and arid climate (Combier 1967; Moncel et al. 1994; Daujeard 2008; Daujeard and Moncel 2010; Moncel et al. 2015). With 1170 bone and teeth remains, reindeer is by far the most abundant species in level 4.1, representing $88 \%$ of the NISP and $55 \%$ of the MNI. The total MNI of the reindeer is estimated at 16 individuals. Horse is the second species, with 75 specimens and four individuals. The richness (2.08) and diversity indexes (Shannon indexes for $\mathrm{MNI}=1.5$ and NISP=0.44; Simpson index=0.81 and 1/D=1.23) and Evenness index for NISP=0.21) are low, highlighting limited diversity regarding the type of species.

Table 2. 
Cervids are the most abundant taxa in level 4.1 with reindeer, red deer and giant deer. Reindeer $(R$. tarandus) were affected by body size variation during the Pleistocene (Bouchud 1966; Delpech 1975; Weinstock 2001; Kuntz 2011), but the bone remains from Abri du Maras level 4.1 are mostly badly preserved and very fragmented and are therefore not suitable elements for a morphometric analysis. Antler preservation also prevents such analysis. Furthermore, the much better preserved teeth seem to be a too stable indicator for this purpose. Red deer remains are also scarce and do not allow for an appropriate discussion of $C$. elaphus status and its biochronological implications. Giant deer ( $M$. giganteus) displays typical dental morphology with a thick cingulum, wide and high entostyle, and strong styles and stylids on both upper and lower molars. Upper premolars are also characterized by a thick, sometimes crenulated cingulum. These elements are consistent with morphologies observed on other Upper Pleistocene specimens (Prat 1968; Lister 1994; Vislobokova 2012).

Only a few elements from horses from level 4.1 are suitable for paleontological and metric analysis. Nevertheless, they all belong to the chrono sub-species E. ferus cf. germanicus, present throughout unit 4. Another equid species is present in level 4.2, Equus hydruntinus, which is only represented by an upper molar with a very similar morphology to that of the sub-species E. hydruntinus davidi. As it is very poorly represented in the sequence, the absence of this most thermophilic species in level 4.1 does not appear significant. From a biochronological point of view, the E. germanicus and E. hydruntinus davidi association is consistent with the chronological attribution of unit 4 to MIS 3 (Guadelli 1987; Boulbes 2009). More precisely, the dimensions of the only complete horse metacarpal present in the level 4.1 are close to those of other series from Tournal cave (B/D levels), Pair-non-Pair or Combe-Grenal, contemporaneous of the beginning of the MIS 3. The few dental elements of large bovids enable us to identify the large steppic bison B. priscus. A number of fish bones, mostly vertebrae, scales and fragments, have been retrieved from the excavation of the squares H6, I6 and J6 (Table S4). Their preservation varies from bad to very good, but fragmentation is high. Out of a total number of 167 fish remains, 46 could be identified to at least the family level. Two families are present: cyprinids (NISP $=34)$ and percids (NISP = 12). Among the cyprinids, the chub (Squalius cephalus) has been identified on the basis of a pharyngeal bone and several vertebrae. Percids are only represented by typical ctenoid scales belonging to the European perch (Perca fluviatilis). Both species are currently common inhabitants of the Ardèche River. Chub size has been estimated through direct comparisons with modern specimens from the reference collection. Estimated body weights range between 550 and $850 \mathrm{~g}$. In the absence of any fish predator at the site, as well as signs of chewing or digestion, the presence of these fish remains in level 4.1 may result from anthropogenic activity. Nevertheless, more information about dating and taphonomic analyses are required to support this assumption.

The micromammals can be assigned to Rodentia, and are represented by a lower right M2 which has been assigned to Microtus ex gr. arvalis-agrestis (MNI = 1). The presence of such species may indicate a rather open environment, although it is impossible to estimate the degree of humidity due to the small number of collected anatomical elements. Some bone surfaces seem to be altered, but no digestion marks were observed and it is therefore not possible to confidently explain the origin of these elements at the site.

Isotopic results from the animal bone collagen extracted and analysed from Abri du Maras level 4.1, are presented in Table 3 ( $n=9 ; \% \mathrm{C}, \% \mathrm{~N}$ and $\mathrm{C}: \mathrm{N}$ also presented) and shown in Figure 5.

\section{Table 3 and Figure 5.}

Apart from a single sample (s-eva-30226), the atomic C:N ratios of the analysed samples range between 3.1 and 3.5, and are therefore within the expected range for well-preserved bone (after van Klinken 1999), a range confirmed by recent experimental data (Dobberstein et al. 2009). The majority of samples have $\% \mathrm{C}$ and $\% \mathrm{~N}$ resembling that of 
modern collagen (van Klinken 1999), and although a minority of samples have <11\%N, C:N ratios all lie within the acceptable range. The collagen preservation displayed in level 4.1 is unusual for material of this age, although collagen has been successfully extracted from other archaeological sites of similar or even older ages in Northern Europe (e.g. Britton et al. 2012, Jones et al. 2001, Richards et al. 2008, Kuitems et al. 2015). As shown in Table 3 and Figure 5, despite the small number of samples, inter-species differences in both $\delta^{13} \mathrm{C}$ and $\delta^{15} \mathrm{~N}$ are apparent, albeit with a greater range in $\delta^{15} \mathrm{~N}$ values. Equus values exhibit both the lowest mean $\delta^{13} \mathrm{C}$ and $\delta^{15} \mathrm{~N}$ values, indicative of grazing, with Rangifer $\delta^{13} \mathrm{C}$ values slightly elevated, which is commonly attributed to the consumption of lichens. However, the most elevated $\delta^{13} \mathrm{C}$ and $\delta^{15} \mathrm{~N}$ values are exhibited in the two Megaloceros samples. This is unusual, as previous isotopes studies of pre-LGM Megaloceros bone collagen from south-west France indicated them occupying a similar niche to red deer (Cervus elaphus) (Immel et al. 2015), with lower $\delta^{13} \mathrm{C}$ (relative to reindeer) associated with leaf feeding in forested environments (Bocherens, 2003, Drucker, et al., 2008). These values are therefore likely reflecting the contemporary environmental and ecological suite of this part of France (i.e. a lack of extensive woodland cover), and also serve to confirm variability in Megaloceros dietary niche, which is consistent with the suggestion that this species was a mixed/opportunistic feeder (Chritz et al. 2009). Elevated $\delta^{13} \mathrm{C}$ values were also determined in Irish Megaloceros dental enamel in a previous study, were related to the consumption of plants such as forb species or sedges, which typically exhibit more positive $\delta^{13} \mathrm{C}$ values (Chritz et al. 2009: 142). The higher $\delta^{15} \mathrm{~N}$ values seen in Megaloceros at Abri du Maras could also be consistent with this. The elevated $\delta^{13} \mathrm{C}$ could also be consistent with the consumption of mosses or lichens, as with reindeer. However, the rumen microbiology of modern (and presumably archaeological) reindeer/caribou, unlike other extant deer species, is adapted for lichen-consumption (Sundset et al. 2008), and it is not known if this would have been the case for Megaloceros. Overall, a range of ca. $3 \%$ is observed in $\delta^{15} \mathrm{~N}$ values across the dataset (from $2.2 \%$ to $5.5 \%$ ), and there are clear inter-species differences, which probably reflect these different niche feeding behaviours.

Tooth microwear data for the reindeer (Table 4) were obtained from eight specimens out of the 14 moulded specimens from level 4.1. Six specimens were excluded for taphonomic reasons (weathering or root alterations). The average number of scratches and pits, as well as the \%0-17, indicate a diet that can be classified as grass-dominated mixed feeding. Compared to other samples of fossil reindeer (Table 4), the population from Abri du Maras is similar to that of Portel-Ouest (Ariège, France) (Fig. 6). The average number of pits, as well as other variables like the percentage of large pits or scratch width, are very similar, suggesting the same dietary traits at both sites. This resemblance is probably related to a similar environmental context in Southern France during the Late Pleistocene. The horse is only represented by two teeth, but even with a very small sample size, the microwear pattern indicates pure grazing (Fig. 7).

\section{Table 4 and Figures 6 and 7.}

The charcoal study was based on the analysis of only 17 charcoal fragments handpicked during the excavation among a great quantity of very small-undetermined fragments. The remains from Abri du Maras are probably related to the use of fuel. Three different taxa, comprising Betula (birch) (13 fragments), Pinus sylvestris type (scots pine type) (2 fragments) and cf. Fabaceae (1 fragment) and 1 undetermined fragment. Betula is the most abundant, however due to the low number of fragments, the taxa should be considered to be equally represented. These results are similar to those from the other layers from Abri du Maras, where Pinus sylvestris type is the most recurrent taxon throughout the sequence (unpublished report; Moncel et al. 2015). However, level 4.1. is the only level with Betula. Pinus sylvestris includes the three mountain types Pinus sylvestris, Pinus uncinata and Pinus nigra ssp. salzmanni, which cannot be 
distinguished due to their similar wood anatomy (Schweingruber 1990). These taxa correspond to heliophilous trees growing under dry and cold conditions. Betula can also grow under cold conditions but needs higher soil humidity rates. Both taxa are colonizer species and could form part of open forests or forest grooves. Betula has also been described in other sites from, for example, Northern Iberia where it is related to increased precipitation and a more humid environment (Uzquiano 2008). The results from the charcoal analyses back up the characterization of mosaic environments during MIS 3 with open landscapes but also arboreal cover. Other European anthracological records show similar patterns with a dominance of conifer forests and Betula as the main arboreal cover. These species would probably coexist, as also observed in other MIS 3 records from Northern Iberia and Central France (Théry-Parisot and Meignen 2000; Théry-Parisot and Texier 2006; Uzquiano 2008; Uzquiano et al. 2008; Uzquiano et al. 2012).

Neanderthal hunting: animal population and seasonality

The 16 reindeer individuals are composed of seven juveniles, two young adults, two prime age adults, three old adults and two senile individuals (Table 2). No foetal remains were discovered, probably because of the differential bone preservation of the sample. This age distribution shows a majority of young individuals. Once plotted on a ternary diagram and after correction as mentioned above in the Methods section, the reindeer population falls into an L-shaped zone (Living structure or catastrophic mortality profiles) (Fig. 8). As noted above, unfortunately, the bad preservation of the reindeer bones and antlers precludes any morphometric and thus sex ratio analyses.

\section{Figure 8.}

Taking into account the period of birth for reindeer (May-June) and the period of death for young individuals, four juveniles died during the fair season (possibly from spring to summer) and five others during the autumn (from September to December). Two juveniles are about 3-5 months old, two are 12-15, one is 17-20 and two are 22-27 months old. Two sub-adults (category young adult) died at the age of 27 to 30 months. Regarding cementochronology, out of the nine studied samples in level 4.1, only four gave positive results (Table S5). They correspond to four reindeer teeth and indicate periods of death during the autumn. These results confirm those based on the periods of tooth eruption, i.e., a majority of animals died during the late summer and autumn. This period corresponds to the present-day great migrations (end of summer and then end of autumn) and rut (October) periods for reindeer (after Miller, 1971), a time of the year when all age classes and both sexes herd together.

Age determination was possible in a small number of individuals of other taxa (Table 2), although ages were mixed and there were insufficient numbers for any clear trends to emerge. The horse series yielded one deciduous foal incisive $(0-3$ months old) indicates a period of death during the summer (births in early May).

The variability of scratch microwear density is used as a proxy for the duration of occupation at archaeological sites. In the case of level 4.1 of Abri du Maras, it corresponds to low variability both in terms of CV and SD (Table 4). Such values fall within the area of seasonal events (or shorter), i.e., area [A] on Figure 6. Values are similar to the signal observed for the reindeer from Salzgitter Lebenstedt (Germany), where animals (MNI = 86) were hunted during a seasonal event in the fall (Gaudzinski and Roebroeks 2000; Rivals et al. 2015). The pattern is significantly different to that reported for longer-term occupations (longer than a season), as at Kent's Cavern (UK) or level G of the Caune de l'Arago (France). 
For reindeer, for the survival rates for each anatomical element, upper and lower long bones largely dominate the distribution (Fig. 9). Among them, we observe a strong and positive correlation between the volume of the marrow cavity and \%MAU of long bone elements (with Spearman's $r s=0.72, \mathrm{df}=9$ and $\mathrm{t}=5.56: \mathrm{p}<0.001$ ). The good representation of tibias, which have the highest marrow content, must be moderated, as it is easier to determine them. Taking into account the seven main carcass portions (\%MAU), the skeletal profile underlines the scarcity of the head and of the limb extremities, the near absence of the vertebral column and the predominance of forequarters and hindquarters (Fig. S5). No correlation exists between FUI indexes and \%MAU for all types of reindeer elements (with Spearman's $\mathrm{rs}=-0.04, \mathrm{df}=13$ and $\mathrm{t}=-0.19: \mathrm{p}>0.8$ ). However, before interpreting these data in terms of human strategies, we have to consider the positive correlation between MAU rates and density indices (see above). This indicates some preservation bias of the bone assemblage. Nevertheless, the deficiency of isolated teeth and cervid antlers confirms the rarity of heads (Figs. 9 and S5). Similarly, the scarcity of basipodials and phalanges cannot be explained by a problem of determination or density and thus highlights a real absence. Finally, it is difficult to specifically determine ribs and vertebrae, but all parts of these elements, even the densest ones, are rare, in the same way as the indeterminate elements belonging to the middle-sized ungulate category. Thus, here too, we can consider the rarity of the trunk as a reality.

\section{Figure 9.}

For the other animals, the number of remains is not sufficient to calculate the MAU, but based on the NISP we can make some comments. For the horse, we observe the same rarity of the trunk (with only one rib fragment) and inversely, the important presence of heads. Two isolated bison teeth and six hindquarter elements are represented: four tibias, one femur and one metatarsal. The megaceros comprises 20 elements, made up of one mandible, one maxillary, one lumbar vertebra, one radius, one hamate, one femur, five tibias and nine metatarsals. Red deer is only represented by six long bone remains: one humerus, one radius, one tibia and one metatarsal. Caprines are represented by four isolated teeth and one femur shaft fragment. As for lagomorphs, rabbit remains comprise one isolated tooth and one metacarpal and the hare one scapula, one humerus and one tibia. Indeterminate lagomorphs regroup two isolated teeth, one scapula, one humerus, one radius, one phalange, one femur, one tibia and two indeterminate elements. $21.8 \%$ of the legible remains bear cut marks, scraping marks and incisions made by sharp lithic tools. All the main ungulate species have been processed (Table 5). Slightly less than a third of the reindeer and horse elements bear cut marks. Some bison, red deer and megaceros portions also show butchery striations. Concerning the chaîne opératoire of carcass processing, depending on the taxa, various stages were processed in the shelter: skinning, dismembering and retrieving tendons, periosteum, flesh, marrow and bone grease removal.

\section{Tables 5 and 6.}

Reindeer include 199 bone elements with cut marks. Most of these are long bone shafts (Table 6). The forelimbs were skinned, as indicated by numerous metacarpal fragments with oblique and parallel incisions of various lengths spread along the anterior and medial faces, and then dismembered (humerus/radius-ulna) and defleshed. This latter step is mostly represented on humerus and radius-ulna by oblique or longitudinal striations spread along the shafts. Tendons were retrieved resulting in transverse marks on the posterior face of some metacarpals. Six fragments of metacarpals bear scraping marks as well as longitudinal long incisions representative of periosteum removal before marrow extraction. One vestigial metapodial displays thirty short and oblique cut marks typical of the skinning process. As for 
the hind limbs, metatarsals point to skin, periosteum and tendon removal, femurs and tibias were defleshed and disarticulation was observed, for tibia/femur on three proximal tibias and for tibia-tarsal on two distal tibia portions and one astragalus with short and deep cut marks on its medial surface. Two fragments of cut-marked mandibles indicate the recovery of cheek meat. Finally, seven rib fragments are cut marked, some due to evisceration, but most of them as a result of defleshing.

For the horse, cut marks show forelimb dismembering (humerus/radius-ulna) and flesh (cheek) removal on two mandible fragments, two tibias and one femur. Bison remains comprise two tibia shaft fragments with filleting marks and one metatarsal fragment with scraping and skinning marks. Evidence of megaceros skinning is present on a metatarsal bone, defleshing on a tibia shaft and evisceration on a lumbar vertebra. One red deer humerus bears a dozen short and deep cut marks on its lateral epicondyle (distal end), indicating disarticulation.

Five of the 10 lagomorph elements highlight the presence of cut marks and/or green bone fracturing. These elements are the distal extremity of a hare humerus, two proximal scapula portions (hare and indeterminate), two femur shaft fragments and a tibia (indeterminate), showing meat removal and the disarticulation process.

Marks with diagnostic criteria of intentional anthropogenic breakage are present on 481 remains of taxonomically identified ungulate long bones. These marks are mainly percussion notches or impact flakes. Incipient percussion pits are rare (1) and peelings were not observed, partly due to the poor conservation of the bone surfaces (root etching). We did not identify any adhering flakes. Concerning positive flake scars, only eight 'boutons de manchette' were observed, mostly in shaft bone fragments (undetermined bones). Long bone shaft parts present the highest rates of percussion marks (99\%), distributed over the diaphysis surface with no preferential location (cf. Vettese, 2014). Only six articular portions display percussion marks. Regarding taxa distribution, the megaceros (33\%) bears the highest proportion of percussion notches, followed by the horse (29\%), red deer and reindeer (25\%) and bison (17\%). Notches are more abundant on tibias and humeri (37\%), femurs (35\%) and then metacarpals (22\%), metatarsals (20\%) and radio-ulnas $(18 \%)$. Apart from long bone elements, a few horse and reindeer mandibles and three calcanei were fractured for recovering marrow. All the phalanges were complete or almost complete.

Burning damage was observed on $20.7 \%$ of the faunal remains (Table S6). The majority of these remains are represented by small fragments with a length of less than $25 \mathrm{~mm}(95.4 \%)$. In that size category, compact bones are dominant. Nevertheless, spongious carbonized bone fragments of all sizes represent a quarter of the burnt elements. The rate of carbonized bone fragments reaches $81.4 \%$. Based on experimental and archaeological data (Costamagno et al. 2009), those data are commonly interpreted to reflect the use of bone for fuel. The low percentage of burnt spongious bones may be due to their high vulnerability to atmospheric agents (Gerbe 2010). Out of the 19 identified burnt bone elements, it is noteworthy that four are short articular bones (one lunate bone, one hamate bone and two malleoli), one is a vertebral element (axis fragment), one is a mandible fragment and 13 are long bone portions (shaft and articular portions).

Lastly, only one small shaft fragment presents retouching marks on its surface. This artefact was burnt (carbonized) and remains indeterminate. The marks are situated on the apical zone and can be associated with sliding striations due to contact with lithic cutting edges. They are short $(<10 \mathrm{~mm})$, dispersed and perpendicular to the long axis (Patou-Mathis and Schwab 2002).

\section{Discussion}

Assessing the origin of a faunal accumulation necessitates the consideration of numerous aspects, such as the archaeological and sedimentological context, as well as taphonomic data. At Abri du Maras, all the data point towards 
an almost exclusively human accumulation. Spatial analyses underline the close association between the faunal and lithic remains unearthed in level 4.1, indicating one distinct occupation phase. Furthermore, the numerous faunal refits ( $n=65-148$ elements) and anatomical connections ( $n=22-68$ elements) identified in this level, associated with the short distances between connecting elements, attest to its homogeneity and sub-contemporaneity. In addition, the numerous butchery marks ( $\approx 20-30 \%$ of the NISP), burnt bones and green bone breakage (70\% of long bones), as well as the absence of carnivore remains and the scarcity of carnivore impacts on bones $(<1 \%)$, allow us to identify this faunal accumulation as human. In this exceptional almost exclusively human accumulation context, data from age and skeletal profiles, as well as seasonality, can be used to assess Neanderthal subsistence behaviours, in a well-defined palaeoenvironmental context.

\section{Palaeolandscapes of MIS 3: a new framework}

The combination of data, such as the faunal spectrum combined with extant herbivore ecological data, isotopes and tooth microwear, enable us to define the palaeoenvironments in level 4.1 at Abri du Maras. The predominance of reindeer in the faunal spectrum, associated with horse and bison suggest open and steppe landscape, while the presence of ibex highlights the rocky landscapes. Additionally, the identification of Microtus arvalis-agrestis within the microfauna supports the idea of an open environment. The presence of (what are typically considered) browsers, such as megaceros and red deer, however, could be indicative of the presence of woodland (see Ecker et al., 2013 for references). Nevertheless, the well-known plasticity of the red deer (Straus 1981; Guérin and Patou-Mathis 1996; Discamps and Royer 2016) associated with the unusual isotope values obtained in this study for the megaceros, contribute to highlight that those species were exploiting different ecological niches. Indeed, whereas the isotope data from horses is typical of grazers, the relatively high $\delta{ }^{13} \mathrm{C}$ observed in megaceros specifically, do not suggest feeding in woodland areas, but instead could indicate mixed-feeding in open environments, indicating that this species was also, like the red deer, an opportunistic feeder. The $\delta^{15} \mathrm{~N}$ values show clear inter-species differences, consistent with various niche feeding behaviours on plants with varying $\delta^{15} \mathrm{~N}$ values. Tooth mesowear and microwear indicate an intermediate position between grass and browse feeders for reindeer and for horse a graze-dominated diet. Data for reindeer and horse are consistent here with those of the carbon stable isotope values, i.e. no clear habitat preference for reindeer (mixed feeder, incorporating lichens or other browse) and contrariwise preference for open landscape grazing for horse. The analysis of red deer bone collagen and tooth wear for megaceros from the site in a future might illuminate the extent of this woodland.

Although broadly a cool, open environment, the pedo-sedimentary facies at the site does suggest occupation during short humid episodes with pronounced pedological development that alternate with drier and cooler phases dominantly marked by accumulation of aeolian dust during the uninhabited periods. This may be indicative of the abandoning of the landscape by Neanderthals during the harshest periods. Finally, charcoal data identify the predominance of birch relatively to scots pine in the level 4.1, indicating sufficient humidity for the development of birch forests. Thus, these data confirm a cool yet moister climate than expected by the faunal spectrum and thus reinforce the characterization of the mosaic environments during the MIS 3 with open lands but also some arboreal cover. Finally, despite the dating margins of error, human occupations of the level 4.1 of Abri du Maras, dated between $40 \pm 3 \mathrm{ky}$ and $46 \pm 3 \mathrm{ky}(n=2)$ (Richard et al. 2015), may correspond to the warm event or Dansgaard-Oeschger event 12 (DO\#12) observed in the Villars speleothem records, just preceding the H4 cooling event, contemporaneous of the Neanderthal demise in western Europe (Genty et al. 2010). According to this study, DO\#12 was likely warm and humid with fast growth rate and low $\delta^{13} \mathrm{C}$, consequence of intense soil and vegetation activity. This is consistent with the contemporaneous pollen record of 
the Monticchio lake which indicates a high percentage of woody taxa (with Quercus, Betula, Ulmus, Fagus), testifying a woody steppe with relatively warm and humid climate (Allen et al. 2000; Genty et al. 2010).

Selective mass reindeer predation at level 4.1 of Abri du Maras?

With $88 \%$ of the NISP, reindeer is the most represented taxon in the faunal spectrum. The richness and diversity indexes highlight a spectrum similar to monospecific ones, such as Les Pradelles (Evenness=0.23 in level 9 and 0.36 in level 10; Costamagno et al. 2006), Le Lazaret-UA25 (Richness=1.41 and Shannon=1.5 for MNI) and the ProtoMagdalenian level of Abri Pataud $(\mathrm{H}<1)$ (see Valensi et al. 2015) for cervids (among others). Large bovid-dominated faunal assemblages are also numerous, with examples such as Mauran (Farizy et al. 1994; E=0.05 and 1/D=1.02, in Grayson and Delpech 2002 and E=0.04 in Rendu et al. 2012), La Borde (Jaubert et al. 1990; E=0.16 and 1/D=1.098, in Grayson and Delpech 2002) in France or Wallertheim in Germany (Gaudzinski 1995). Even dangerous and solitary species such as the rhinoceros were selectively hunted by humans with the famous example of Taubach in Germany (Bratlund 2000). Mass mammoth hunting by driving is postulated for the Saalian site of La Cotte Saint Brelade in Jersey (Scott, in Callow and Cornford 1986). According to the study of Gaudzinski-Windheuser (2006), such anthropogenic mono-specific faunal spectra increased significantly all over Europe from MIS 5 onwards (see also above in the Introduction).

The age distribution of the 16 reindeer individuals from level 4.1 indicates a living structure. Age profiles pointing to catastrophic mortality are representative of natural disasters, mass kills or non-selective hunting episodes (Lyman 1987; Stiner 1990; Discamps and Costamagno 2015).Mass kills or non-selective slaughters within the herds are both plausible. Similar age profiles have been observed for other Middle Palaeolithic cervid accumulations, such as Salzgitter-Lebenstedt (MNI=86), Les Pradelles (Level 9, MNI=33; Level 10, MNI=22), Roc de Marsal (Layer 4, MNI=12/estimated MNI=78), Jonzac (Layer 22, MNI=18) or Pech de l'Azé IV (layer 4, MNI=25) for reindeer (Gaudzinski and Roebroeks 2000; Costamagno et al. 2006; Niven et al. 2012; Niven 2013; Castel et al. 2016), as well as Pech de l'Azé I (Level 4, MNI=19) for red deer (Rendu et al. 2010), considered to be the result of non-selective hunting. Inversely, some bovid-dominated assemblages, such as Wallertheim (Level B1, MNI=52) (Gaudzinski 1995), show repeated, selective and controlled collective hunting episodes, indicating that human strategies are not the same, depending on the hunted species and environments. All these sites display one single dominated species, and the only difference lies in the number of individuals, mainly depending on the excavated surfaces and the number of human occupation episodes.

At Abri du Maras, seasonality indices can be linked to human hunting activities. Indeed, added to the presence of unretouched Levallois points used as projectile tips and large Levallois blades and points brought to the site (Hardy et al., 2013; Moncel et al., 2014), the taphonomic analysis (see above) clearly associates the faunal assemblage with planned hunting activities. The seasonal indices for level 4.1 show that most of the reindeer deaths occurred during the autumn (September to December). Furthermore, tooth microwear data correspond to seasonal events, similar to those observed for reindeer from Salzgitter, which reflect short-term mass death scenarios during the same period around September. The three short-term stopping places of Les Pradelles, Jonzac and Salzgitter show the same period of death for reindeer (Gaudzinski and Roebroeks 2000; Costamagno et al. 2006; Niven et al. 2012), coinciding with the reindeer's fall migrations. Fall migration is a time of the year where herds are not segregated and males (before and during the rut) and females are in particularly good physical condition, optimizing energy return for hunters. Even amongst sedentary ecotypes, Fall is the period where body condition is optimal and fat reserves are highest in Rangifer, 
following Summer feeding. Unusually, at Pech de l'Azé IV, humans seem to have hunted reindeer during their spring migration.

Concerning the skeletal profiles, long bones largely dominate the accumulation, and among them, the richest elements in marrow, indicating primary carcass processing on the kill site and then selective transport of the carcass elements. The scarcity of the axial skeleton (head and trunk) and of the limb extremities (short articular bones) could indicate their abandonment at the kill site and/or an in situ differential and/or spatial preservation or treatment (grease bone extraction, use of bone as fuel). These data may be related to the significant and positive correlation between bone density and the \%MAU, highlighting the rarity of the less dense bone portions on the site (mainly long bone extremities and axial skeleton). Nevertheless, as indicated above, the rarity of isolated teeth and antlers confirms the absence of the heads. Concerning the trunk, all portions are scarce, even the densest ones and also indeterminate elements. Thus, the near-absence of the axial skeleton cannot be entirely explained by the post-depositional destruction of low-density elements and we can instead postulate that these parts were frequently abandoned at the kill site and/or exploited and thus destroyed by Neanderthals once transported to the site. As for the paucity of carpals and tarsals, the presence of metapodials and of other limb portions at the site raises questions as to their in situ disappearance. As these parts are not particularly fragile, this may also result from specific in situ treatment rather than differential preservation. The scarcity of phalanges is more easily explained, suggesting the hypothesis of skin exportation. However, specific spongious bone processing at the site (for fuel or grease extraction), including articular portions as well as vertebral elements, may also be a valid explanation.

At Roc de Marsal, interestingly, the authors (Castel et al. 2016) observe the same scarcity of heads (including antlers), short articular elements, phalanges and the axial skeleton, as a result of the combination of different causes: in situ differential preservation, in situ specific treatment and the abandonment of some carcass elements at the kill site. Concerning spongious bone treatment, the main difference between both sites lies in the lack of fire evidence at Roc de Marsal and conversely in the many fire indices at Abri du Maras: ash lenses and numerous burnt bones. Nevertheless, other types of carcass exploitation behaviours exist in the Middle Palaeolithic reindeer-dominated assemblages. For example, at Jonzac, the skeletal profiles indicate the transport of whole carcasses to the site, whereas at Les Pradelles (Levels 9 and 10), which is considered as a secondary butchery site, Neanderthals may have mostly selected upper long bones and then exported some fleshy portions to another camp. Due to the absence of evidence of fire and the presence of carnivore tooth marks on bones at Les Pradelles, the same hypotheses regarding the scarcity of spongious bone elements at this site cannot be advanced. At Pech de l'Azé IV, the most nutritious body parts were selectively transported to the site. At the open-air site of Salzgitter-Lebenstedt, the data point towards the hunting of high-quality animals and the in situ processing of limb bone elements for flesh and marrow, with possible evidence of food storage, as at Les Pradelles (Gaudzinski and Roebroeks 2000; Costamagno et al. 2006). In general, in all these reindeerdominated assemblages, except those of Salzgitter and Jonzac, which served as primary butchering locations where reindeer skeletons were mostly retrieved complete, we observe a deficiency of the axial skeleton (heads, vertebrae and ribs), as well as the girdles (pelvis and scapula) and the short articular bones (carpals, tarsals and phalanges). All these parts cannot be equally affected by low-density differential preservation, and thus large carcass portions appear to have been abandoned at the kill site during the early butchery stages (disarticulation) and/or affected by specific anthropogenic treatment at the base camp (grease bone extraction and/or use of bones as fuel). The lack of fire in many of these places, such as Roc de Marsal, Pech de l'Azé IV (layer 4), Les Pradelles, Jonzac or Salzgitter, may point towards a combination of the frequent abandonment of the trunk, short articular bones, heads with antlers, as well as skins, including phalanges and in situ grease extraction of the transported spongious elements. This moderate presence of skulls and minor presence of phalanges, associated with a representation of the limb bones relative to marrow 
contents, has already been highlighted for reindeer assemblages from the Middle Palaeolithic (Gaudzinski-Windheuser and Niven 2009).

Finally, at Abri du Maras, the numerous cut marked elements, associated with the almost systematic green bone breakage of limb elements for marrow recovery and the possible use of bones for fuel, indicate intensive in situ carcass treatment and consumption. All stages of the butchery process are identified: from evisceration, to skinning, disarticulation, defleshing and the removal of tendons. Nevertheless, due to the lack or the scarcity of certain skeletal parts (vertebrae, ribs and long bone extremities), evisceration and disarticulation are very poorly represented. As for long bone breakage for marrow, $85 \%$ of the long bone remains bear green bone fractures. This rate is high, but still moderate compared to other anthropogenic faunal assemblages where the near totality of yellow marrow bones are fractured, including not only long bones, but also phalanges, tarsals and mandibles (i.e. Les Pradelles or Roc de Marsal in south-western France: Costamagno et al. 2006; Castel et al. 2016 or Saint-Marcel or Sainte-Anne I in the Southeast: Daujeard 2007; Daujeard et al. 2012). Here, very few mandibles and calcanei and no phalanges present green bone breakage. Some anatomical connections (limb bone elements) and whole long bones, especially reindeer metacarpals, were found in level 4.1. The same behaviour has also been observed at Jonzac and Salzgitter-Lebenstedt, where, at the latter site, Neanderthals frequently discarded poor long bone elements and some metacarpals were abandoned whole. In all these reindeer-dominated assemblages, evidence of in situ meat filleting and marrow exploitation by Neanderthals has been documented, associated with very scarce indices of carnivore action. The rarity of the presence of traces of fire, only recorded in the level 4.1 of Abri du Maras, may indicate different site functions and possibly longer occupation durations.

At Abri du Maras (level 4.1), the clear monospecific spectrum, catastrophic mortality and autumnal deaths point to short-term hunting episodes of migratory mixed herds. At that time of the year, Neanderthal groups focused on preferential prey, predominantly available in the surroundings. However, as underlined by Costamagno et al. (2006), the question of 'obligate' versus 'deliberate' specialization is very difficult to assess (see below). Likewise, it is very difficult to discern between successive individual hunting episodes and mass kills. Many criteria, such as sedimentation rates, refits and the volume of the excavation must be taken into account for evaluating the presence of a single depositional episode. Unfortunately, these data are difficult to obtain in the literature and thus difficult to compare. What can be said of Abri du Maras (level 4.1) is that the presence of numerous short distances refits and of ash lenses at a same depth seems to suggest a main phase of human occupation. Like most of the reindeer-dominated assemblages (except for Salzgitter), level 4.1 has a high MNI of reindeer (between 10 and 30) and indicates that hunters regularly discarded carcass portions at the kill site. Added to the predominance of reindeer in the assemblage and catastrophic and seasonal mortality (Costamagno et al. 2006; Rendu et al. 2012; Lubinski 2013), mass procurement is the most likely explanation.

Finally, at Abri du Maras, carcasses were clearly being butchered elsewhere at the kill site and then the limb elements were commonly selected to be transported to the site. The presence of some long bones, still complete or even in anatomical connections, as at the site of Salzgitter-Lebenstedt, further supports the hypothesis that level 4.1 is predominantly the product of mass hunting episodes.

\section{Neanderthal hunting of reindeer in the Upper Pleistocene of Western Europe: selective and planned behaviour or environmental constraints?}

Reindeer-dominated assemblages are a specific type of single species-dominated assemblage, associated with a seasonal hunting model. This is the case at Les Pradelles, Jonzac, Roc de Marsal, Pech de l'Azé IV in south-western France or 
Salzgitter in the north of Europe. Some authors argue that such assemblages result from the opportunistic response of Neanderthals to taxa availability (Niven et al. 2012; Niven 2013). Neanderthals may have hunted reindeer because of their dominance during cold periods and because of the lack of other ungulates in the environment, such as bison or horse. This observation is similar to that of Grayson and Delpech (2003) for the Magdalenian assemblages at Grotte $\mathrm{XVI}$, where the increase in reindeer remains is interpreted as a direct reflection of what was available in the environment during periods of cold summer temperatures. Similarly, on a regional scale, the study of Magniez and Boulbes (2014) at Tournal Cave underlines the important role of environmental changes on the dietary behaviour of human groups during the Upper Pleistocene, from MIS 3 to MIS 2. This point of view is also supported by the data from Discamps (2013), showing important biomass fluctuations between the Quina and post-Quina periods in southwestern France. According to that author, the Quina period corresponds to a low ungulate biomass episode marked by growing reindeer populations. Inversely, during the late Middle Palaeolithic, or 'Post-Quina' period, ungulate biomass increases with the highest rates of horse and bison. Nevertheless, more recent palaeoenvironmental reconstruction from large and small mammal communities (Discamps and Royer 2016) tempers those chronological changes in the SouthWest, underlining the importance of seasonal and geographical differences. Indeed, the latter is illustrated in the SouthWest for the Quercy region, where a high ungulate biomass environment persists during the Quina episode (Discamps 2013). About seasonality influence, it should be noted that while limited strontium isotope evidence suggests migratory behavior in late Pleistocene European reindeer, this has yet to be demonstrated for bison (Britton et al. 2011, Julien et al. 2012). One other notable factor is that the faunal spectra of the reindeer monospecific assemblages of Jonzac and Pech de l'Azé IV, as well as in all Upper Pleistocene assemblages of this type, whether they are in Western or Northern Europe, always comprise horse, bison and red deer alongside reindeer. Finally, the recent TL ages of Guérin et al. (2016) at Roc de Marsal (average of $49 \mathrm{ky}, n=5$ ) suggest a longer duration for the Quina Mousterian with reindeerdominated assemblage in south-western France, extending until MIS 3, very close to the ages obtained for level 4.1 of Abri du Maras. These new TL ages (Guérin et al. 2012, 2016) also confirm the association of some Levallois assemblages with mixed fauna (red deer, roe deer and reindeer) at the beginning of MIS 4 (ca. 65-70 ky) and that of others with reindeer-dominated spectra at certain moments of MIS 3 in south-western France (Rendu et al. 2014). All those data invalidate the strict association of MIS 4 with Quina technological complex and reindeer-dominated spectra in that region, providing a more complex view of palaeoenvironmental evolution during MIS 4 and MIS 3. Thus, taking into account those difficulties in chronological resolution and environmental reconstruction, we may keep in mind the possibility that this monospecific reindeer hunting behaviour may rather reflect a preferential selection of prey, than environmental constraints (see Castel et al. 2016).

In south-eastern France, a different situation emerges with a very low number of reindeer-dominated assemblages for the Upper Pleistocene. Other Middle Palaeolithic and even Early Middle Palaeolithic single species-dominated assemblages with seasonal slaughters have been observed in the south-east. This is the case at Sainte-Anne I, SaintMarcel, Abri Moula (interglacial levels) and Le Lazaret (UA25), with spectra largely dominated by cervids or at Baume des Peyrards, in the Vaucluse, where the ibex is the main hunted animal (Daujeard and Moncel 2010; Moncel and Daujeard 2012; Daujeard et al. 2012). Nonetheless, only some Late Middle Palaeolithic occupation phases, Baume Néron, Abri Moula and Abri du Maras, all situated along the Rhône Valley, show faunal spectra dominated by reindeer and followed by bison and horse. All these assemblages correspond to the end of MIS 4 or the beginning of MIS 3 (Defleur et al. 1994; Defleur et al. 2001; Richard et al. 2015), with cold and humid environments. At Abri du Maras, we observe different faunal spectra within a same sedimentary unit and chronological time span (Richard et al. 2015). Indeed, level 4.2, which is situated just below level 4.1, provides a more varied faunal spectrum dominated by bison and horse and followed by red deer, reindeer and megaceros. Besides that, preliminary seasonal data for the horse and 
megaceros from level 4.2 give different periods of human occupations, during the spring and the summer (Daujeard, in Moncel et al. 2014, unpublished report). Thus, the differences existing between these two sub-contemporaneous levels may be explained here by the planned seasonal organization of Neanderthal groups, depending on the presence of some species in the surroundings, at local and short chronological scales, rather than on a real absence of other animal community. Indeed, the reindeer dominated-assemblage in level 4.1 could result from selective hunting by highly mobile human populations, who knew the location of shallow river crossings (natural fords), facilitating the passage of animals across the Ardèche River, and also possibly the timing reindeer migrations along the Rhône Valley. If reindeer were indeed migratory at this time period, and in this region, the hunting of non-migratory 'local' animals, in smaller numbers (relative to reindeer) could also be an important buffer against the time-stress activity of interception hunting. Were the reindeer herds targeted non-migratory, and instead exhibited more local ranging behavior, other factors could explain this selection. For example, the aggregations of males and females that occur during the rut in both migratory and sedentary herds, and the prime condition of the animals during Autumn (in terms of body weight and fat percentage). The strontium isotope analysis of reindeer teeth from Level 4.1 of Abri du Maras would serve to illuminate this further, and help determine if reindeer targeted were indeed migratory. However, whether it was to intercept migratory herds, or to take advantage of the Autumn aggregations of prime conditioned reindeer herds (migratory or non-migratory), the intense and seasonally-restricted nature of reindeer exploitation at Abri du Maras infers the selective, seasonal appeal of this area for contemporary groups on their seasonal rounds . At Abri du Maras, this behaviour, highlighting planned and communal mass hunting strategies, seems here to "imply a deliberate selection of particular species from the total resources potentially available for exploitation” (Mellars 1996: 196). Significantly, Abri du Maras confirms the deeper antiquity of the practice in another region of Europe than previously identified (mainly south-western France and Northern Germany).

Thus, the faunal analysis of level 4.1 of Abri du Maras provides evidence of a new occurrence of planned, collective and selective Middle Palaeolithic reindeer hunting, considerably further east than other well-known sites in southwestern France, such as Les Pradelles, Jonzac, Roc de Marsal or Pech de l'Azé IV. Indeed, south-eastern France displays rare cases of reindeer-dominated assemblages along the Rhône valley. The sites of Abri du Maras, Abri Moula and Baume Néron present faunal spectra representative of cold and humid occupation phases related to the last glaciation, at the end of MIS 4 and beginning of MIS 3. The main difference with the south-western assemblages, is that, with Salzgitter, these assemblages are all associated with a predominantly Levallois production (points and elongated products) with very few or no Quina retouches. At Salzgitter, a Micoquian series including Keilmesser-types is associated moreover with the Levallois debitage (Tode et al. 1953). Thus, it is interesting to note that the model advanced by Delagnes and Rendu (2011) for the South-West, with a Quina system associated with well-planned reindeer exploitation, a discoid-denticulate system reflecting more opportunistic behaviours related to bison or horse hunting and a Levallois technology related to foraging mobility with no selective hunting, cannot be applied to other regions. Finally, at Abri du Maras, we must underline that part of tool kit production, such as the use of some points used as projectiles, was planned before arriving on the site. This far-sighted lithic behaviour may be related to the planning of reindeer herd slaughtering by Neanderthal groups. However, despite that observation, we do not observe a link as clear as that observed in the South-West between planned monospecific hunting strategies and lithic technologies, adding to the complexity of the scenario.

\section{Conclusion}


The integration of multiple analyses undertaken on the faunal assemblages from level 4.1 at Abri du Maras enabled us to define Neanderthal subsistence behaviours at the site within a precise chronological and palaeoenvironmental framework. Pedo-sedimentary facies, charcoal, stable isotope and tooth wear suggest a cool, but moist regional environment, different from what is highlighted by the faunal spectrum alone, i.e. harsher, steppic conditions. The chronological attribution of the level (beginning of the MIS 3 between $40 \pm 3 \mathrm{ky}$ and $46 \pm 3 \mathrm{ky}$, probably between the Heinrich events H5 and H4, cf. Richard et al. 2015) is consistent with the D-O \#12 event recorded in the Villars speleothems (Genty et al. 2010), characterised by a woody steppe with a relatively warm and humid climate compared to earlier periods. At Abri du Maras, the almost-exclusive anthropogenic accumulation of the fauna in level 4.1 represents an exceptional framework to interpret human subsistence strategies. Here, the reindeer-dominated assemblage is representative of planned and collective Neanderthal hunting activities during the Autumn. The clear monospecific spectrum, associated with seasonal evidence and the selective transport of some carcass portions to the site, points to short-term mass hunting episodes of reindeer herds, not well recognized until now in the south-eastern France for that period. It can be speculated that reindeer were either hunted during their seasonal migrations and they were not present in the region all year round (i.e. they were a seasonally restricted resource), or, if they were the sedentary ecotype, they were exploited during their Autumn aggregations when both male and females tend to be in prime condition, in terms of body weight and body fat percentage (i.e. they were a seasonally selected resource). Future analyses of materials from the site, such as strontium isotope analysis of reindeer tooth enamel, will provide insights into whether or not the herds targeted by Neanderthals at Abri du Maras were migratory, and further illuminate the nature of this assemblage and therefore the main motivations underlying the regular Autumnal activities of the human groups in this region.

In addition to the otherwise specialized nature of Neanderthal activities at Abri du Maras, evidence presented here are also suggestive of more diverse subsistence strategies at the site. For example, the evidence for numerous episodes of fire use and the in situ consumption of meat, marrow and bone grease. In addition, lithic debitage, woodworking, and possibly manufacturing string or nets (Hardy et al. 2013), point to mainly non-specialized activities, possibly evidencing adaptable and diverse seasonal behaviours. This corroborates the regional mobility model that has been previously proposed for this region of south-eastern France, i.e. a far-sighted circulating model very closely associated with regional micro-topography and available seasonal resources (biotopes and raw material outcrops) (Daujeard and Moncel 2010; Daujeard et al. 2016). Many Middle Palaeolithic assemblages with monospecific fauna indicate secondary butchery processing with evidence of food storage and no or scant use of fire, indicating short-term human occupations. At Abri du Maras, we cannot confidently associate short-term hunting episodes with short-term occupations of the site, and one does not necessarily preclude the other. Further investigations combining faunal, lithic and spatial analyses will permit to have a better idea of the type and duration of the human occupations within the level 4.1. Finally, data of the sub-contemporaneous faunal assemblage from level 4.2 will provide precious additional data for understanding fluctuations in Neanderthal subsistence strategies in the same topographical context in a later period, and under a different climatic regime.

\section{Acknowledgements}

Fieldwork was supported by the Regional Office of Archaeology Rhône-Alpes, the French Ministry of Culture and Communication and the Ardèche Department through several scientific programs. M.G.Chacon, F. Rivals and E. Allué research are funded by "CERCA Programme/Generalitat de Catalunya". Thanks to Jean-Jacques Hublin, Annabell 
Reiner and Steven Steinbrenner from the Max Planck Institute (MPI-EVA) for analytical support (isotope analysis).The English manuscript was edited by L. Byrne, an official translator and native English speaker.

\section{References}

Airvaux J (ed) (2004) Le Site Paléolithique de Chez-Pinaud à Jonzac, Charente-Maritime. Premiers Résultats : Etudes sur la Coupe Gauche. Préhistoire du Sud-Ouest, Supplément, vol. 8. Association Préhistoire du Sud-Ouest, Cressensac. Antoine, P., 2002. Les loess en France et dans le Nord-Ouest européen. Rev fr géotech 99:3-21

Behrensmeyer AK (1978) Taphonomic and ecologic information from bone weathering. Palaeobiology 4:150-162

Behrensmeyer AK, Gordon KD, Yanagi GT (1986) Trampling as a cause of bone surface damage and pseudo-cutmarks. Nature 319:768-771

Ben-David M, Shochat E, Adams LG (2001) Utility of stable isotope analysis in studying foraging ecology of herbivores: examples from moose and caribou. ALCES 37(2):421-434

Bignon O (2003) Diversité et exploitation des équidés au Tardiglaciaire en Europe occidentale. Implications pour les stratégies de subsistance et les modes de vie au Magdalénien et à l'Azilien ancien du Bassin parisien. Dissertation,

University of Paris X, Nanterre

Binford LR (1978) Nunamiut Ethnoarchaeology. Academic Press, New York

Binford LR (1981) Bones: Ancient men and modern myths. Academic Press, New York

Binford LR (1984) Faunal Remains from Klasies River Mouth. Academic Press, New York

Binford LR (1988) Etude taphonomique des restes fauniques de la Grotte Vaufrey, couche VIII. In: Rigaud J-P (ed) La Grotte Vaufrey: paléoenvironnement, chronologie, activités humaines. Mémoires de la Société Préhistorique Française 19 , pp 535-564

Blasco R, Rosell J, Peris JF, Caceres I, Vergès JM (2008) A new element of trampling: an experimental application on the Level XII faunal record of Bolomor Cave (Valencia, Spain). J Archaeol Sci 35:1605-1618.

Blasco R, Rosell J, Domínguez-Rodrigo M, Lozano S, Pastó I, Riba D, Vaquero M, Peris JF, Arsuaga JL, de Castro JMB, Carbonell E (2013) Learning by Heart: Cultural Patterns in the Faunal Processing Sequence during the Middle Pleistocene. Plos One 8(2)

Blumenschine RJ, Selvaggio MM (1988) Percussion marks on bone surfaces as a new diagnostic of hominid behavior. Nature 333:763-765

Blumenschine RJ, Marean CW, Capaldo SD (1996) Blind tests of inter-analyst correspondence and accuracy in the identification of cut marks, percussion marks, and carnivore tooth marks on bone surfaces. J Archaeol Sci 23:493-507 Bocherens H (2003) Isotopic biogeochemistry and the palaeoecology of the mammoth steppe fauna. DEINSEA Annual of the Natural History Museum Rotterdam 9:57-76 
Bouchud J (1966) Essai sur le renne et la climatologie du Paléolithique supérieur et moyen. Périgueux, Imprimerie

Magne

Boulbes N (2009) Etude comparée de la denture d'Equus hydruntinus (Mammalia, Perissodactyla) dans le Sud-Est de la France. Implications biogéographiques et biostratigraphiques. Quaternaire 20 (4):449-465

Bratlund B (2000) Taubach revisited. Jahrbuch des Römisch -Gennanischen Zentralmuseums Mainz 46, pp 61-174 Britton K, V Grimes, L Niven, T Steele, S McPherron, M Soressi, TE Kelly, J Jaubert, JJ Hublin, MP Richards (2011) Strontium isotope evidence for migration in late Pleistocene Rangifer: Implications for Neanderthal hunting strategies at the Middle Palaeolithic site of Jonzac, France. J Hum Evol 61:176-185

Britton K, Gaudzinski-Windheuser S, Roebroeks W, Kindler L, Richards MP (2012) Stable isotope analysis of wellpreserved 120,000-year-old herbivore bone collagen from the Middle Palaeolithic site of Neumark-Nord 2, Germany reveals niche separation between bovids and equids. Palaeogeogr Palaeoclimatol Palaeoecol 333-334:168-177

Brochier JL (1976) Les cailloux à perforations de lichens. Leur rapport à l'étude sédimentologiques d'un remplissage. Bull Assoc fr Étude quat 13:53-54

Brown TA, DE Nelson, JS Vogel, JR, Southon (1988) Improved collagen extraction by modified Longin method. Radiocarbon 30(2):171-177

Brugal JP, David F (1993) Usure dentaire, courbe de mortalité et « saisonnalité » : les gisements du Paléolithique moyen à grands bovidés. In: Desse $\mathrm{J}$, Audoin-Rouzeau $\mathrm{F}$ (eds), Exploitation des animaux sauvages à travers le temps, XIIIème Rencontres Internationales d'Archéologie et d'Histoire d'Antibes, IVème Colloque international de l'Homme et de l'Animal, Société de Recherche Interdisciplinaire, APDCA, Sophia Antipolis, pp 63-77

Burke A (1993) Observation of incremental growth structures in dental cementum using the scanning electron microscope. Archaeozoologia 5(2):41-54

Burke A (2000) The view from Starosele: faunal exploitation at a Middle Palaeolithic Site in Western Crimea. Int J Osteoarchaeol 10:325-335

Burke A (2006) Neanderthal settlement patterns in Crimea: A landscape approach. J Anthropol Archaeol 25:510-523

Campmas E, Beauval C (2008) Consommation osseuse des carnivores : résultats de l'étude de l'exploitation de carcasses de boeufs (Bos taurus) par des loups captifs. L’Anthropologie 94:167-186

Canti M (1998) Origin of calcium carbonate granules found in buried soils and Quaternary deposits. Boreas 27:275-288 Capaldo SD, Blumenschine RJ (1994) A Quantitative Diagnosis of Notches Made by Hammerstone Percussion and Carnivore Gnawing on Bovid Long Bones. Am Antiq 59(4):724-748 
Caparrós M, Barroso Ruiz C, Moigne AM, Monclova Bohorquez A (2012) Did Neanderthals and Carnivores Compete for Animal Nutritional Resources in the Surroundings of the Cave of Zafarraya? Journal of Taphonomy 10(3-4):395415

Castel JC, Discamps E, Soulier MC, Sandgathe D, Dibble HL, McPherron SP, Goldberg P, Turq A (2016) Neandertal subsistence strategies during the Quina Mousterian at Roc de Marsal (France). Quatern Int, in press, doi.org/10.1016/j.quaint.2015.12.033

Cerling TE, Hart JA, Hart TB (2004) Stable Isotope Ecology in the Ituri Forest. Oecologia 138:5-12 Chase PG (1986) The Hunters of Combe-Grenal: Approaches to Middle Paleolithic Subsistence in Europe. British Archaeological Reports International Series S286

Chritz KL, Dyke GJ, Zazzo A, Lister AM, Monaghan NT, Sigwart JD (2009) Palaeobiology of an extinct Ice Age mammal: Stable isotope and cementum analysis of giant deer teeth. Palaeogeogr Palaeoclimatol Palaeoecol 282(14):133-144

Collins MJ, Galley P (1998) Towards an optimal method of archaeological collagen extraction: the influence of $\mathrm{pH}$ and grinding. Ancient Biomolecules 2:209-222

Combier J (1967) Le Paléolithique de l'Ardèche dans son cadre bioclimatique. Delmas, Bordeaux

Costamagno S, David F (2009) Comparaison des pratiques bouchères et culinaires de différents groupes sibériens vivant de la renniculture. Archaeofauna 19:9-25

Costamagno S, Meignen L, Beauval C, Vandermeersch B, Maureille B (2006) Les Pradelles (Marillac-le-Franc, France): A mousterian reindeer hunting camp? J Anthropol Archaeol 25:466-484

Costamagno S, Théry-Parisot I, Castel JC, Brugal JP (2009) Combustible ou non ? Analyse multifactorielle et modèles explicatifs sur des ossements brûlés paléolithiques. In: Théry-Parisot I, Costamagno S, Henry A (eds) Fuel Management during the Paleolithic and Mesolithic Periods. New tools, new interpretations, BAR International Series 1914, pp 65-84 Cruz-Uribe K (1991) Distinguishing hyena from hominid bone accumulations. J Field Archaeol 18:467-486 Daujeard C (2007) Exploitation intensive des carcasses de cerf dans le gisement paléolithique moyen de la grotte de Saint-Marcel (Ardèche). XXVIème Congrès de la Société Préhistorique française, Avignon, 21-25 septembre 2004, vol 3 , pp 481-497

Daujeard C (2008) Exploitation du milieu animal par les Néanderthaliens dans le Sud-Est de la France. BAR International Series, vol. S1867. Archaeopress, Oxford Daujeard C (2014) Le matériel faunique. In: Moncel (dir.), Abri du Maras (Saint-Martin d'Ardèche). Service Régional de l'Archéologie Rhône-Alpes (unpublished report) 
Daujeard C, Moncel MH (2010) On Neanderthal subsistence strategies and land use: a regional focus on the Rhône

Valley area in southeastern France. J Anthropol Archaeol 29(3):368-391

Daujeard C, Fernandes P, Guadelli JL, Moncel MH, Santagata C, Raynal JP (2012) Neanderthal subsistence strategies in Southeastern France between the plains of the Rhône Valley and the mid-mountains of the Massif Central (MIS 7 to MIS 3). Quatern Int 252:32-47

Daujeard C, Abrams G, Germonpré M, Le Pape JM, Wampach A, Di Modica K, Moncel MH (2016) Neanderthal and animal karstic occupations from southern Belgium and south-eastern France: Regional or common features? Quatern Int 411:179-197

David F, Enloe JG (1993) L'exploitation des animaux sauvages de la fin du Paléolithique moyen au Magdalénien. In: Desse, J, Audoin-Rouzeau F (eds) Exploitation des Animaux Sauvages à travers le Temps. 13e Rencontres Internationales d'Archéologie et d'Histoire d'Antibes, APDCA-CNRS, Sophia Antipolis, pp 29-47

Debard E (1988) Le Quaternaire du Bas-Vivarais d'après l'étude des remplissages d'avens, de grottes et d'abris sous roche. Dynamique sédimentaire, paléoclimatologie et chronologie. Doc Lab Géologie Lyon 103

Defleur A, Bez JF, Crégut-Bonnoure E, Desclaux E, Fontugne M, Jeannet M, Magnon F, Talon B, Thinon M, Combier J (1994) Industries, biostratigraphie, restes humains et datation du gisement moustérien de la Baume Néron (Soyons, Ardèche). CR Acad Sci Paris 318(II):1409-1414

Defleur A, Crégut-Bonnoure E, Desclaux E, Thinon M (2001) Présentation paléoenvironnementale du remplissage de la Baume Moula-Guercy à Soyons (Ardèche) : implications paléoclimatiques et chronologiques. L’Anthropologie 105(3):369-408

Delagnes A, Rendu W (2011) Shifts in Neandertal mobility, technology and subsistence strategies in western France. J Archaeol Sci 38:1771-1783

Delpech F (1983) Les faunes du Paléolithique supérieur dans le Sud-Ouest de la France. Cahiers du Quaternaire 6 CNRS, Paris

Discamps E (2013) Ungulate biomass fluctuations endured by Middle and Early Upper Paleolithic societies (SW France, MIS 5-3): the contributions of modern analogs and cave hyena paleodemography. Quatern Int 337:64-79 Discamps E, Costamagno S (2015) Improving mortality profile analysis in zooarchaeology: a revised zoning for ternary diagrams. J Archaeol Sci 58:62-76

Discamps E, Royer A (2016) Reconstructing palaeoenvironmental conditions faced by Mousterian hunters during MIS 5 to 3 in southwestern France: A multi-scale approach using data from large and small mammal communities. Quatern Int, in press, doi? 
Dobberstein RC, Collins MJ, Craig OE, Taylor G, Penkman KEH, Ritz-Timme S (2009) Archaeological collagen: Why

worry about collagen diagenesis? Archaeol Anthropol Sci 1(1):31-42

Domínguez-Rodrigo M, de Juana S, Galan AB, Rodriguez M (2009) A new protocol to differentiate trampling marks from butchery cut marks. J Archaeol Sci 36 (2643-2654)

Drucker D, Bocherens H, Pike-Tay A, Mariotti A (2001) Isotopic tracking of seasonal dietary change in dentine collagen: preliminary data from modern caribou. Earth Planet Sci Lett 333:303-309

Drucker DG, A Bridault, Hobson KA, Szuma E, Bocherens H (2008) Can carbon-13 in large herbivores reflect the canopy effect in temperate and boreal ecosystems? Evidence from modern and ancient ungulates. Palaeogeogr

Palaeoclimatol Palaeoecol 266(1-2):69-82

Drucker DG, Hobson KA, Münzel SC, Pike-Tay A (2012) Intra-individual variation in stable carbon $(\delta 13 C)$ and nitrogen $(\delta 15 \mathrm{~N})$ isotopes in mandibles of modern caribou of Qamanirjuaq (Rangifer tarandus groenlandicus) and Banks Island (Rangifer tarandus pearyi): Implications for tracing seasonal and temporal changes in diet. Int J Osteoarchaeol 22(4):494-504

Ecker M, Bocherens H, Julien MA, Rivals F, Raynal JP, Moncel MH (2013) Middle Pleistocene ecology and Neanderthal subsistence: Insights from stable isotope analyses in Payre (Ardèche, France). J Hum Evol 65:363-373 Farizy C, David E, Jaubert J (1994) Hommes et bison du Paléolithique moyen à Mauran (Haute Garonne). CNRS (ed) Paris

Feranec RS (2007) Stable carbon isotope values reveal evidence of resource partitioning among ungulates from modem C-3-dominated ecosystems in North America. Palaeogeogr Palaeoclimatol Palaeoecol 252(3-4):575-585

Fisher JW (1995) Bone surface modifications in zooarchaeology. J Archaeol Method Th 2:7-68

Forsten A, Moigne AM (1998) The horse from the middle pleistocene of Orgnac 3 (Ardèche, France). Quaternaire 9 (4):315-323

Fu QM, Hajdinjak, Moldovan S, Constantin S, Mallick P, Skoglund N, Patterson N et al. (2015) An early modern human from Romania with a recent Neanderthal ancestor. Nature 524 (7564): 216-219

Gaudzinski S (1995) Wallertheim revisited: a re-analysis of the fauna from the Middle Palaeolithic site of Wallertheim (Rheinhessen, Germany). J Archaeol Sci 22:51-66

Gaudzinski S (1996) On bovid assemblages and their consequences for the knowledge of subsistence patterns in the Middle Palaeolithic. Proc Prehist Soc 62:19-39

Gaudzinski-Windheuser S (2006) Monospecific or species-dominated faunal assemblages during the Middle Paleolithic in Europe. In: Hovers E, Kuhn SL (eds) Transitions before the Transition. Springer, New York, pp 137-147 
Gaudzinski S, Roebroeks W (2000) Adults only. Reindeer hunting at the Middle Palaeolithic site Salzgitter-Lebenstedt,

Northern Germany. J Hum Evol 38:497-521

Gaudzinski-Windheuser S, Niven L (2009) Hominin subsistence patterns during the Middle and Late Paleolithic in Northwestern Europe. In: Hublin JJ, Richards MP (eds) The Evolution of Hominid Diets: Integrating Approaches to the Study of Palaeolithic Subsistence. Springer, Dordrecht, pp 97-109

Gaudzinski-Windheuser S, Kindler L (2012) Research perspectives for the study of Neandertal subsistence strategies based on the analysis of archaeozoological assemblages. Quatern Int 247:59-68

Gautier A (1989) Preliminary notes on the fauna of the middle Palaeolithic site at Zwolen (Poland). Liège. In: Otte M (ed) L’Homme de Néandertal. La Subsistance. Vol. 6, ERAUL 33, Liège, pp 69-73

Genty D, Combourieu-Nebout N, Peyron O, Blamart D, Wainer K, Mansuri F, Ghaleb B, Isabello L, Dormoy I, von Grafenstein U, Bonelli S, Landais A, Brauer A (2010) Isotopic characterization of rapid climatic events during OIS3 and OIS4 in Villars Cave stalagmites (SW-France) and correlation with Atlantic and Mediterranean pollen records.

Quat Sci Rev 29:2799-2820

Gerbe M (2010) L’action des agents atmosphériques (weathering) sur des ossements brûlés : approche expérimentale. In: Théry-Parisot I, Chabal L, Costamagno S (eds)Taphononomie des résidus organiques brûlés et des structures de combustion en milieu archéologique. Actes de la table ronde, Valbonne, 27-29 mai 2008. P@lethnologie 2:182-201 Gilles R (1950) Présentation des silex taillés d'un abri-sous-roche du département de l'Ardèche. Bull Soc Préhist Fr $47: 202$

Grant A (1982) The use of tooth wear as a guide to the age of domestic ungulates. In: Wilson B, Grigson C, Payne S (eds) Ageing and Sexing Animal Bones from Archaeological Sites, British Archaeological Reports International Series, S109, pp 91-108

Grayson DK, Delpech F (2002) Specialized early upper Palaeolithic hunters in Southwestern France? J Archaeol Sci 29:1439-1449

Grayson DK, Delpech F (2003) Ungulates and the Middle-to-Upper Paleolithic transition at Grotte XVI (Dordogne, France). J Archaeol Sci 30:1633-1648

Green RE, Krause J, Briggs AW, Maricic T, Stenzel E, Pääbo S et al (2010) A Draft Sequence of the Neandertal Genome. Science 328:710-722

Guadelli JL (1987) Contribution à l'étude des zoocénoses préhistoriques en Aquitaine (Würm ancien et interstade würmien). Dissertation, University of Bordeaux I

Guadelli JL (1998) Détermination de l'âge des chevaux fossiles et établissement des classes d'âge. Paleo 10:87-93 
Guadelli JL (2008) La gélifraction des restes fauniques. Expérimentation et transfert au fossile. Annls Paléont (Vert) 94

\section{(3):121-165}

Hardy BL, Moncel MH, Daujeard C, Fernandes P, Béarez P, Desclaux E, Chacon Navarro MG, Puaud S, Gallotti R (2013) Impossible Neanderthals? Making string, throwing projectiles and catching small game during Marine Isotope Stage 4 (Abri du Maras, France). Quat Sci Rev 82:23-40

Haynes G (1983) A guide for differentiating mammalian carnivore taxa responsible for gnaw damage to herbivore limb bones. Palaeobiology 9(2):164-172

Heaton THE, Vogel JC, von la Chevallerie G, Collett G (1986) Climatic influence on the isotopic composition of bone nitrogen. Nature 322:822-823

Hoffecker JF, Baryshnikov G, Potapova O (1991) Vertebrate remains from the mousterian site of II'skaja I (Northern Caucasus USSR): New analysis and interpretation. J Archaeol Sci 18:113-147

Immel A, Drucker D, Bonazzi M, Jahnke TK, Münzel SC, Schuenemann VJ, Herbig A, Kind CJ, Krause J (2015) Mitochondrial Genomes of Giant Deers Suggest their Late Survival in Central Europe. Scientific Reports 5:10853 Jaillard B, Guyon A, Maurin AF (1991) Structure and composition of calcified roots, and their identification in calcareous soils. Geoderma 50 (197-210)

Jaubert J, Lorblanchet M, Laville H, Slot-Moller R, Turc A, Brugal JP (1990) Les Chasseurs d'Aurochs de La Borde. La Maison des Sciences de l'Homme (ed), Paris

Jones KT, Metcalfe D (1988) Bare bones archaeology: bone marrow indices and efficiency. J Archaeol Sci 15 (415423)

Jones AM, O'Connell TC, Young ED, Scott K, Buckingham CM, Lacumin P, Brasier MD (2001) Biogeochemical data from well preserved 200 ky collagen and skeletal remains. Earth Planet Sci Lett 193(1-2):143-149

Julien MA, Bocherens H, Burke A, Drucker D, Patou-Mathis M, Krotova O, Péan S (2012) Were European steppe bison migratory? 180, 13C and $\mathrm{Sr}$ intra-tooth isotopic variations applied to a palaeoethological reconstruction. Quatern Int 271(0):106-119

Julien MA, Rivals F, Serangeli J, Bocherens H, Conard NJ (2015) A new approach for deciphering between single and multiple accumulation events using intra-tooth isotopic variations: Application to the Middle Pleistocene bone bed of Schöningen 13 II-4. J Hum Evol 89:114-128

Kitagawa K, Kronneck P, Conard NJ, Münzel SC (2012) Exploring cave use and exploitation among cave bears, carnivores and hominins in the Swabian Jura, Germany. Journal of Taphonomy 10(3-4):439-461

Klein RG, Cruz-Uribe C (1984) The Analysis of Animal Bones from Archaeological Sites. University of Chicago Press 
van Klinken GJ (1999) Bone collagen quality indicators for palaeodietary and radiocarbon measurements. J Archaeol

Sci 26:687-695

van Klinken GJ, Richards MP, Hedges REM (2000) An overview of causes for stable isotopic variations in past European human populations: Environmental, ecophysiological, and cultural effects. In: Ambrose S, Katzenberg A (eds) Biogeochemical approaches to palaeodietary analysis, Kluwer Academic/Plenum publishers, New York, pp 39-63 Kooistra MJ, Pulleman MM (2010) Features related to faunal activity. In: Stoops G, Marcelino V, Mees F (eds) Interpretation of micromorphological features of soils and regoliths. Elsevier, Amsterdam, pp 397-418 Kuitems M, van der Plicht J, Drucker DG, van Kolfschoten T, Palstra SWL, Bocherens H (2015) Carbon and nitrogen stable isotopes of well-preserved Middle Pleistocene bone collagen from Schöningen (Germany) and their palaeoecological implications. J Hum Evol 89:105-113

Kuntz D (2011) Ostéométrie et migration(s) du Renne (Rangifer tarandus) dans le sud-ouest de la France au cours du dernier Pléniglaciaire et du Tardiglaciaire (21 500-13 000 cal. B.P.). Dissertation, University of Toulouse II - Le Mirail Lam YM, Chen X, Pearson OM (1999) Intertaxonomic variability in patterns of bone density and the differential representation of bovid, cervid, and equid elements in the archaeological record. Am Antiq 64:343-362

Lieberman D, Deacon T, Meadow R (1990) Computer image enhancement and analysis of cementum increments as applied to the teeth of Gazella gazella. J Archaeol Sci 17 (519-533)

Lister AM (1994) The evolution of the giant deer, Megaloceros giganteus (Blumenbach), Zoological Journal of the Linnean Society 112:65-100

Longin R (1971) New method of collagen extraction for radiocarbon dating. Nature 230:241-242

Lubinski PM (2013) What is adequate evidence for mass procurement of ungulates in zooarchaeology? Quatern Int 297:167-175

Lyman RL (1987) On the analysis of vertebrate mortality profiles: sample size, mortality profile, and hunting pressure. Am Antiq 52:125-142

Lyman RL (1994) Vertebrate Taphonomy. Cambridge University Press, Cambridge, MA

Lyman RL (2004) The concept of equifinality in taphonomy. Journal of Taphonomy 2(1):15-26

Magniez P, Boulbes N (2014) Environment during the Middle to Late Palaeolithic transition in southern France: The archaeological sequence of Tournal Cave (Bize-Minervois, France). Quatern Int 337:43-63

Magurran AE (1988) Ecological Diversity and its Measurement. Princeton: Princeton University Press Marean CW (1998) A critique of the evidence for scavenging by Neandertals and early modern humans: new data from Kobeh Cave (Zagros Mountains, Iran) and Die Kelders Cave 1 Layer 10 (South Africa). J Hum Evol 35:111-136 
Mellars P (1996) The Neandertal Legacy: an archaeological perspective from Western Europe. Princeton University

Press, Princeton

Metcalfe D, Jones KT (1988) A reconsideration of Animal Body-Part Utility Indices. Am Antiq 53:486-504

Miller FL (1974) Biology of the Kaminuriak population of barren-ground caribou. Part 2: Dentition as indicator of age and sex; composition and socialization of the population. Can Wildl Serv Rep Ser 31:1-88

Moncel MH, Michel V (2000) Première tentative de datation par U-Th du site paléolithique moyen de l'abri du Maras. Bull Soc Préhist Fr 93(3):371-375.

Moncel MH, Daujeard C (2012) The variability of the Middle Palaeolithic on the right bank of the Middle Rhône Valley (southeast France): Technical traditions or functional choices? Quatern Int 247:103-124

Moncel MH, Gaillard C, Patou-Mathis M (1994) L'Abri du Maras (Ardèche) : une nouvelle campagne de fouilles dans un site paléolithique moyen. Bull Soc Préhist Fr 91(6):363-368

Moncel MH, Daujeard C, Cregut-Bonnoure E, Boulbes N, Puaud S, Debard E, Bailon S, Desclaux E, Escude E, Roger T, Dubar M (2010) Nouvelles données sur les occupations humaines du début du Pléistocène supérieur de la moyenne vallée du Rhône (France). Les sites de l'Abri des Pêcheurs, de la Baume Flandin, de l'Abri du Maras et de la Grotte du Figuier (Ardèche). Quaternaire 21(4):389-415

Moncel MH, Moigne AM, Combier J (2012) Towards the Middle Palaeolithic in Western Europe: The case of Orgnac 3 (southeastern France). J Hum Evol 63:653-666

Moncel MH, Chacon Navarro MG, La Porta A, Fernandes P, Hardy B, Gallotti R (2014) Fragmented reduction processes: Middle Palaeolithic technical behaviour in the Abri du Maras shelter, southeastern France. Quatern Int 350:180-204

Moncel MH, Allué E, Bailon S, Barshay-Szmidt C, Béarez P, Crégut-Bonnoure E, Daujeard C, Desclaux E, Debard E, Lartigot-Campin AS, Puaud S, Roger T (2015) Evaluating the integrity of palaeoenvironmental and archaeological records in MIS 5 to 3 karst sequences from southeastern France. Quatern Int 378:22-39

Nilssen PJ (2000) An actualistic butchery study in South Africa and its implications for reconstructing hominid strategies of carcass acquisition and butchery in the Upper Pleistocene and Plio-Pleistocene. Dissertation, University of Cape Town

Niven L, Steele TE, Rendu W, Mallye JB, McPherron SP, Soressi M, Jaubert J, Hublin JJ (2012) Neandertal mobility and large-game hunting: The exploitation of reindeer during the Quina Mousterian at Chez-Pinaud Jonzac (CharenteMaritime, France). J Hum Evol 63:624-635 
Niven L (2013) A diachronic evaluation of Neanderthal cervid exploitation and site use at Pech de l'Azé IV, France. In:

Clark J, Speth J (eds) Zooarchaeology and Modern Human Origins: Human Hunting Behavior during the Later

Pleistocene. Springer Verlag, Dordrecht, pp 151-161

Noe-Nygaard N, Price TD, Hede SU (2005) Diet of aurochs and early cattle in southern Scandinavia: evidence from $15 \mathrm{~N}$ and $13 \mathrm{C}$ stable isotopes. J Archaeol Sci 32:855-871

Nowak M (2013) Identification de téphras dans le remplissage sédimentaire du site préhistorique de l'Abri du Maras (Saint-Martin-d'Ardèche, Ardèche) : essai de caractérisation -physico-chimie, origine et chronologie). Dissertation, Muséum national d'Histoire naturelle, Paris

Oakley KP, Andrews P, Keeley LH, Clark JD (1977) A reappraisal of the Clacton spearpoint. Proc Prehist Soc 43:1330

Olsen SL, Shipman P (1988) Surface modification on bone: trampling versus butchery. J Archaeol Sci 15:535-553 Patou-Mathis M (1997) Apport de l'archéozoologie à la connaissance des comportements de subsistance des hommes du Paléolithique. In: Patou-Mathis M, Otte M (eds) L'alimentation des hommes du Paléolithique : approche pluridisciplinaire, ERAUL 83:277-292

Patou-Mathis M (1998) Les espèces chassées et consommées par l'homme en couche 5. In: Otte M, Patou-Mathis M, Bonjean D (eds) Recherches aux grottes de Sclayn, L'Archéologie, vol 2, Université de Liège, Liège, pp 297-310 Patou-Mathis M (1999) Zooarchaeology analysis of the middle Paleolithic fauna from selected levels of Kabazi II. In: Chabaï VP, Monigal K (eds) The Middle Paleolithic of Western Crimea, vol 2, ERAUL 87:41-74

Patou-Mathis M (2000) Neanderthal subsistence behaviours in Europe. Int J Osteoarchaeol 10:379-385

Patou-Mathis M, Schwab C (2002) Fiche générale. In: Patou-Mathis M (ed) Industrie de l'os préhistorique: compresseurs, percuteurs, retouchoirs, vol X, Société préhistorique française ed, pp 11-20

Pickering TR (2002) Reconsideration of criteria for differentiating faunal assemblages accumulated by hyenas and hominids. Int J Osteoarchaeol 12:127-141

Pike-Tay A (1991) Red deer Hunting in the Upper Paleolithic of Southwest France: A Study in Seasonality. British Archaeological Reports International Series S569, Oxford: Tempus Reparatum

Pike-Tay A (1995) Variability and synchrony of seasonal indicators in dental cementum microstructure of the Kaminuriak Rangifer population. Archaeofauna 4:273-284

Pobiner BL, Rogers MJ, Monahan CM, Harris JWK (2008) New evidence for hominin carcass processing strategies at 1.5 Ma, Koobi Fora, Kenya. J Hum Evol 55:103-130

Prat F (1968) Sur des vestiges de Mégacéros découverts dans quelques gisements paléolithiques du Sud-Ouest de la France. Dissertation, University of Bordeaux I 
Price TD, Meiggs D, Weber MJ, Pike-Tay A (2015) The migration of Late Pleistocene reindeer: isotopic evidence from

northern Europe. Archaeol Anthropol Sci 1-24

Puaud S, Nowak M, Pont S, Moncel MH (2015) Minéraux volcaniques et alpins à l'abri du Maras (Ardèche, France) : témoins de vents catabatiques dans la vallée du Rhône au Pléistocène supérieur. C R Palevol 14:331-341

Rendu W (2010) Hunting behavior and Neanderthal adaptability in the late Pleistocene site of Pech-de-l'Azé I. J Archaeol Sci 37:1798-1810

Rendu W, Costamagno S, Meignen L, Soulier MC (2012) Monospecific faunal spectra in Mousterian contexts: Implications for social behavior. Quatern Int 247:50-58

Rendu W, Beauval C, Crevecoeur I, Bayle P, Balzeau A, Bismuth T, Bourguignon L, Delfour G, Faivre JP, LacrampeCuyaubère F, Tavormina C, Todisco D, Turq A, Maureille B (2014) Evidence supporting an intentional Neandertal burial at La Chapelle-aux-Saints. PNAS 111(1):81-86

Richard M, Falguères C, Pons-Branchu E, Bahain JJ, Voinchet P, Lebon M, Valladas H, Dolo JM, Puaud S, Rué M, Daujeard C, Moncel MH, Raynal JP (2015) Contribution of ESR/U-series dating to the chronology of late Middle Palaeolithic sites in the middle Rhône valley, southeastern France. Quat Geochronol 30(B):529-534

Richards MP, Hedges REM (2003) Variations in bone collagen delta C-13 and delta N-15 values of fauna from Northwest Europe over the last 40000 years. Palaeogeogr Palaeoclimatol Palaeoecol 193(2):261-267

Richards MP, Taylor G, Steele T, McPherron SP, Soressi M, Jaubert J, Orschiedt J, Mallye JB, Rendu W, Hublin JJ (2008) Isotopic dietary analysis of a Neanderthal and associated fauna from the site of Jonzac (Charente-Maritime), France. J Hum Evol 55(1):179-185

Riglet PH (1977) Contribution à l'étude de l'âge du cerf élaphe (Cervus elaphus L.). Dissertation, National Veterinary School of Alfort

Rivals F, Prignano L, Semprebon GM, Lozano S (2015) A tool for determining duration of mortality events in archaeological assemblages using extant ungulate microwear. Scientific Reports 5:17330

Rivals F, Julien MA, Kuitems M, Van Kolfschoten T, Serangeli J, Drucker DG, Bocherens H, Conard NJ (2015) Investigation of equid paleodiet from Schöningen 13 II-4 through dental wear and isotopic analyses: Archaeological implications. J Hum Evol 89:129-137

Rivals F, Lister AM (2016) Dietary flexibility and niche partitioning of large herbivores through the Pleistocene of Britain. Quat Sci Rev 146:116-133

Rogers AR (2000) On equifinality in faunal analysis. Am Antiq 65:709-723

Schoch WH, Bigga G, Böhner U, Richter P, Terberger T (2015) New insights on the wooden weapons from the Paleolithic site of Schöningen. J Hum Evol 89:214-225 
Schwarcz HP, TL Dupras, SI Fairgrieve (1999) 15N Enrichment in the Sahara: In Search of a Global Relationship. J

Archaeol Sci 26(6):629-636

Schweingruber FH (1990) Anatomie europäischer Hölzer ein Atlas zur Bestimmung europäischer Baum-, Strauch- und Zwergstrauchhölzer Anatomy of European woods an atlas for the identification of European trees shrubs and dwarf shrubs. Verlag Paul Haupt, Stuttgart

Scott K (1986) The large mammal fauna. In: Callow, P., Cornford, J.M. (Eds.), La Cotte de St. Brelade 1961-1978.

Excavations by C.B.M. McBurney. GeoBooks, Norwich, pp 109-139

Semprebon GM, Godfrey LR, Solounias N, Sutherland MR, Jungers WL (2004) Can low-magnification stereomicroscopy reveal diet? J Hum Evol 47:115-144

Semprebon GM, Rivals F (2007) Was grass more prevalent in the pronghorn past? An assessment of the dietary adaptations of Miocene to recent Antilocapridae (Mammalia: Artiodactyla). Palaeogeogr Palaeoclimatol Palaeoecol $253: 332-347$

Shipman P, Rose JJ (1983) Early hominid hunting, butchering, and carcass processing behaviors: approaches to the fossil record. J Anthropol Archaeol 2:57-98

Shipman P, Rose JJ (1984) Cutmark Mimics on Modern and Fossil Bovid Bones. Current Anthropology 25(1):116-117 Simpson EH (1949) Measurement of diversity. Nature 163(4148):688-688

Solounias N, Semprebon G (2002) Advances in the reconstruction of ungulate ecomorphology with application to early fossil equids. Am Mus Novit 3366:1-49

Stevens RE, Hedges REM (2004) Carbon and nitrogen stable isotope analysis of northwest European horse bone and tooth collagen, 40,000 BP-present: Palaeoclimatic interpretations. Quat Sci Rev 23(7-8):977-991

Stevens RE, Jacobi R, Street M, Germonpre M, Conard NJ, Munzel SC, Hedges REM (2008) Nitrogen isotope analyses of reindeer (Rangifer tarandus), 45,000 BP to 900 BP: Palaeoenvironmental reconstructions. Palaeogeogr

Palaeoclimatol Palaeoecol 262(1-2):32-45

Stiner MC (1990) The use of mortality patterns in archaeological studies of hominid predatory adaptations. J Anthropol Archaeol 9:305-351

Stiner MC (1994) Honor among thieves - A Zooarchaeological Study of Neandertal Ecology. Princeton University Press

Stiner MC, Kuhn SL, Weiner S, Bar-Yosef O (1995) Differential burning, recrystallization, and fragmentation of archaeological bones. J Archaeol Sci 22:223-237

Sundset MA, Kohn A, Mathiesen SD, Præsteng KE (2008) Eubacterium rangiferina, a novel usnic acid-resistant bacterium from the reindeer rumen. Naturwissenschaften 95(8):741-749 
Szpak P (2014) Complexities of nitrogen isotope biogeochemistry in plant-soil systems: implications for the study of

ancient agricultural and animal management practices. Frontiers in Plant Science 5

Théry-Parisot I, Meignen L (2000) Économie des combustibles (bois et lignite) dans l'abri moustérien des Canalettes. Gallia Préhistoire $42: 45-55$

Théry-Parisot I, Texier PJ (2006) La collecte du bois de feu dans le site moustérien de la Combette (Bonnieux, Vaucluse, France): implications paléo-économiques et paléo-écologiques. Approche morphométrique des charbons de bois. Bull Soc Préhist Fr 453-463

Thieme H (1997) Lower Palaeolithic hunting spears from Germany. Nature 385, 805-810

Tode A, Preul F, Richter K, Selle W, Pfaffenberg K, Kleinschmidt A, Guenther EW, Müller A, Schwartz W (1953) Die Untersuchung der paläolithischen Freilandstation von Salzgitter-Lebenstedt. Quaternary Science Journal 03(1) A14:144-220

Uzquiano P, Arbizu Senosiain MA, Arsuaga JL, Adán Álvarez GE, Aranburu Artano A, Iriarte Avilés E (2008) Datos paleoflorísticos en la Cuenca media del Nalón entre 40-32 Ka. BP: antracoanálisis de la Cueva del Conde (Santo Adriano, Asturias). Cuaternario y Geomorfología 22:121-133

Uzquiano P (2008) Domestic fires and vegetation cover among Neanderthalians and Anatomically Modern Human groups (> 53 to 30 Kyrs BP) in the Cantabrian Region (Cantabria, Northern Spain). Charcoal from the Past: Cultural and Palaeoenvironmental implications, pp 273-285

Uzquiano P, Yravedra J, Zapata BR, Garcia MJG, Sesé C, Baena J (2012) Human behaviour and adaptations to MIS 3 environmental trends (> 53-30 ky BP) at Esquilleu cave (Cantabria, northern Spain). Quatern Int 252:82-89

Valensi P, Michel V, El Guennouni K, Liouville M (2013) New data on human behavior from a 160,000 year old Acheulean occupation level at Lazaret cave, south-east France: An archaeozoological approach. Quatern Int 316:123139

Vettese D (2014) Le traitement boucher des carcasses d'ongulés chez les Néanderthaliens de l'Abri du Maras (Ardèche, MIS4) : individualisme ou poids des traditions ? Dissertation, Muséum national d'Histoire naturelle, Paris

Villa P, Mahieu E (1991) Breakage patterns of human long bones. J Hum Evol 21:27-48

Vislobokova IA (2012) Giant Deer: Origin, Evolution, Role in the Biosphere. Palaeontological Journal 46(7):643-775

Weinstock J (2000) Late Pleistocene reindeer populations in Middle and Western Europe, an osteometrical study of Rangifer tarandus. BioArchaeologica, Tubingen, vol 3

Wilson B (1989) Fresh and old table refuse. The recognition and location of domestic activity at archaeological sites in the Upper Thames Valley, England. Archaeozoologia 3:237-260 
Yravedra J, Cobo-Sánchez L (2015) Neanderthal exploitation of ibex and chamois in southwestern Europe, J Hum Evol $1 \quad 78: 12-32$

2

3

4

5

6

7

8

10

11

12

13

14

15

16

17

18

19

20

21

22

23

24

25

26

27

28

29

30

31

32

33

34

35

36

37

38

39

40

41

42

43

44

45

46

47

48

49

50

51

52

53

54

55

56

57

58

59

60

61

62

63

64

65 


\begin{tabular}{llllll}
\hline & NTR & NISPa & Coordinated & Isolated teeth & Illegible bone remains \\
\hline NR & 11123 & 1347 & 2919 & 231 & 902 \\
$\%$ & $100.0 \%$ & $12.1 \%$ & $26.2 \%$ & $17.1 \%$ & $33.2 \%$ \\
\hline
\end{tabular}

Table 1. Bone preservation indexes (NTR: number of total bone remains).

\begin{tabular}{|c|c|c|c|c|c|}
\hline Taxa & NISP & $\%$ NISP & $\mathrm{MNI}$ & $\% \mathrm{MNI}$ & Age class \\
\hline Equus ferus cf. germanicus & 75 & $6.4 \%$ & 4 & $13.8 \%$ & 1J, 1YA, 1PA, 1OA \\
\hline Perissodactyla & 75 & $6.4 \%$ & 4 & $13.8 \%$ & \\
\hline Rangifer tarandus & 1030 & $88.0 \%$ & 16 & $55.2 \%$ & 7J, $2 Y A, 2$ PA, 3OA, $2 S$ \\
\hline Cervus elaphus & 6 & $0.5 \%$ & 1 & $3.4 \%$ & - \\
\hline Megaloceros giganteus & 20 & $1.7 \%$ & 2 & $6.9 \%$ & $10 A$ \\
\hline Cervidae indet. & 11 & $0.9 \%$ & & & - \\
\hline Capra ibex & 2 & $0.2 \%$ & 1 & $3.4 \%$ & - \\
\hline Caprinae indet. & 3 & $0.3 \%$ & & & - \\
\hline Bison priscus & 8 & $0.7 \%$ & 2 & $6.9 \%$ & 1J, 1YA \\
\hline Artiodactyla & 1080 & $92.3 \%$ & 22 & $75.9 \%$ & \\
\hline Lepus sp. & 3 & $0.3 \%$ & 2 & $6.9 \%$ & $1 J$ \\
\hline Oryctolagus cuniculus & 2 & $0.2 \%$ & 1 & $3.4 \%$ & - \\
\hline Leporidae indet. & 10 & $0.9 \%$ & & & - \\
\hline Lagomorpha & 15 & $1.3 \%$ & 3 & $10.3 \%$ & \\
\hline Total NISP/MNI & 1170 & $100.0 \%$ & 29 & $100.0 \%$ & \\
\hline
\end{tabular}

Table 2. Large and small mammal spectrum for level 4.1. Number of Identified Specimen (NISP), Minimal Number of Individuals (MNI) and age data (J: juvenile, YA: young adult, PA: prime age adult, OA: old adult, S: senile).

\begin{tabular}{llllllll}
\hline s-eva no. & Taxa & Bone & $\delta^{13} \mathrm{C}$ & $\delta^{15} \mathrm{~N}$ & $\% \mathrm{C}$ & $\% \mathrm{~N}$ & $\mathrm{C}: \mathrm{N}$ \\
\hline 30051 & Equus & Metacarpal III & -20.6 & 4.8 & 28.0 & 9.4 & 3.5 \\
30050 & Equus & Mandible & -20.3 & 3.2 & 35.0 & 12.0 & 3.4 \\
30226 & Equus & Mandible & -24.9 & 1.0 & 2.4 & 0.4 & 6.9
\end{tabular}




\begin{tabular}{llllllll}
30052 & Equus & Mandible & -20.0 & 2.2 & 31.4 & 11.1 & 3.3 \\
30053 & Megaloceros & Mandible & -19.3 & 5.5 & 28.3 & 10.2 & 3.2 \\
30054 & Megaloceros & Maxilla & -19.4 & 5.4 & 27.8 & 9.9 & 3.3 \\
30056 & Rangifer & Mandible & -19.8 & 4.7 & 26.9 & 9.5 & 3.3 \\
30057 & Rangifer & Mandible & -20.0 & 5.3 & 36.1 & 13.2 & 3.2 \\
30055 & Rangifer & Mandible & -19.9 & 4.2 & 32.0 & 11.6 & 3.2 \\
\hline
\end{tabular}

Table 3. Stable carbon $\left(\delta^{13} \mathrm{C}\right)$ and nitrogen $\left(\delta^{15} \mathrm{~N}\right)$ isotope ratios of faunal bone collagen extracted from level 4.1, including \%C, \%N and C:N.

\begin{tabular}{lccccccccc}
\hline Locality & N & NP & NS & SD & CV & \%LP & SWS & $\%$ XS & $\% 0-17$ \\
\hline Abri du Maras & 8 & 20.06 & 18.25 & 2.299 & 0.126 & 0.0 & 1.13 & 37.5 & 25.0 \\
Salzgitter Lebenstedt (1) & 82 & 29.12 & 10.87 & 1.827 & 0.170 & 47.6 & 0.94 & 4.9 & 97.6 \\
Kent's Cavern (2) & 12 & 15.50 & 15.63 & 4.012 & 0.257 & 25.0 & 1.33 & 50.0 & 75.0 \\
Portel-Ouest F (1) & 30 & 23.23 & 25.35 & 3.097 & 0.122 & 3.3 & 1.13 & 60.0 & 0.0 \\
Caune de l'Arago G (1) & 11 & 14.15 & 17.41 & 4.380 & 0.281 & 12.0 & 0.88 & 35.0 & 52.9 \\
\hline
\end{tabular}

Table 4. Tooth microwear summary for the reindeer ( $R$. tarandus) from level 4.1 of Abri du Maras and other Middle and Late Pleistocene localities (data from (1) Rivals et al. 2015 and (2) Rivals and Lister, 2016). Abbreviations: $\mathrm{N}=$ Number of specimens; $N P=$ average number of pits; $N S=$ average number of scratches; $S D=$ standard deviation on NS; CV = coefficient of variation on NS; \%LP = percentage of individuals with large pits; SWS = scratch width score; \%XS = percentage of individuals with cross scratches; $\% 0-17=$ percentage of individuals with less than 17 scratches i.e. within the browsing range.

\begin{tabular}{llll}
\hline Taxa & NRcut & NRI & $\%$ NRcut \\
\hline Equus ferus cf. germanicus & 8 & 26 & $30.8 \%$ \\
Bison priscus & 3 & 4 & - \\
Cervus elaphus & 1 & 2 & - \\
Megaloceros giganteus & 3 & 14 & $21.4 \%$ \\
Rangifer tarandus & 199 & 719 & $27.7 \%$ \\
Lagomorphs & 5 & 10 & $50.0 \%$
\end{tabular}




\begin{tabular}{llll} 
IND coord & 230 & 1288 & $17.9 \%$ \\
Total & 449 & 2063 & $21.8 \%$ \\
\hline
\end{tabular}

Table 5. Number (NRcut) and rates (\%NRcut) of cut marked remains by taxa (NRI: Number of legible remains).

\begin{tabular}{|c|c|c|c|}
\hline & NRcut & NISPI & \%NRcut \\
\hline Mandible & 2 & 17 & 11.8 \\
\hline Ribs & 7 & 36 & 19.4 \\
\hline Humerus & 15 & 45 & 33.3 \\
\hline Radius-Ulna & 25 & 115 & 21.7 \\
\hline Metacarpal & 20 & 53 & 37.7 \\
\hline Femur & 13 & 26 & 50.0 \\
\hline Tibia & 55 & 152 & 36.2 \\
\hline Astragalus & 1 & 2 & - \\
\hline Metatarsal & 45 & 155 & 29.0 \\
\hline Metapodials & 12 & 54 & 22.2 \\
\hline Vestigial metapodials \& phalanges & 2 & 4 & - \\
\hline Indeterminate shafts & 2 & - & - \\
\hline
\end{tabular}

Table 6. Number (NRcut) and rates (\%NRcut) of cut marked elements for reindeer (NISPI: Number of legible identified specimen). 
Figure captions

Figure 1. Location of the Abri du Maras. Site situation on the edges of the Rhône valley in the context of the south-eastern Middle Palaeolithic (Map adapted from Tessier, in Daujeard et al., 2011).

Figure 2. GIS projections of the faunal and lithic items on the stratigraphic profile: band 6 in unit 4 (Figure by R. Gallotti and Simon Puaud).

Figure 3. Two refitted tibia fragments of a large cervid: Cervus or Megaloceros (level 4.1, J6-85 and J6-85/1) (Photos by D. Vettese and M.G. Chacon).

Figure 4. Photo of a reindeer metacarpal fragment. This fragment presents green bone fractures and a whole distal portion (level 4.1, J6-39) (Photo by C. Daujeard).

Figure 5. Stable carbon $(\delta 13 \mathrm{C})$ and nitrogen $(\delta 15 \mathrm{~N})$ isotope ratios of faunal bone collagen extracted from level 4.1 (Graph by K. Britton).

Figure 6. Microwear data (Graph by F. Rivals). Boundary lines with the error probability (heat map) based on SD and CV values of microwear data used for the classification of samples into short events (region A), long-term events (region B), or two separated short events (region C). Black dots indicate modern reindeer populations used to build the model. White stars indicate archaeological samples: Abri du Maras (level 4.1), Salzgitter Lebenstedt (SL), Portel-Ouest level F (PO-F), Kent's Cavern (KC), and Caune de l'Arago level G (CA-G).

Figure 7. Bivariate plot of the average densities of pits and scratches in reindeer and horse (Graph by F. Rivals). Bars correspond to the standard deviation ( $\pm 2 \mathrm{SD}$ ) for the fossil samples. Grey areas correspond to the Gaussian confidence ellipses $(p=0.95)$ on the centroid for extant leaf browsers $(B)$ and grazers (G) from Solounias and Semprebon (2002).

Figure 8. Ternary diagram for reindeer age classes (modified from Stiner, 1990) (Graph by C. Daujeard).

Figure 9. Distribution of the skeletal elements for reindeer by anatomical parts (Graph by C. Daujeard). Survival rates calculation corresponds to MAU*100/NMImax. 


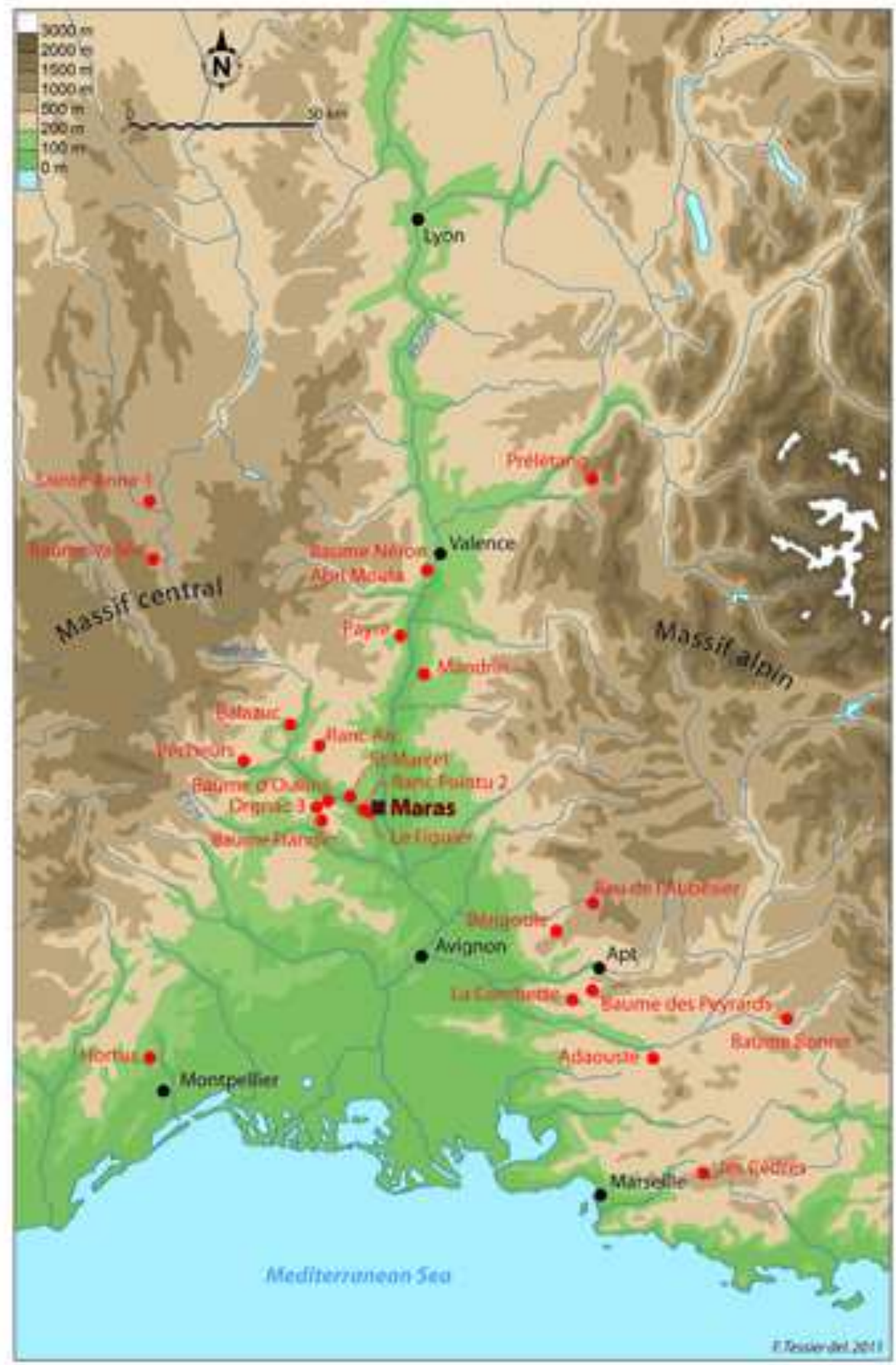


sir
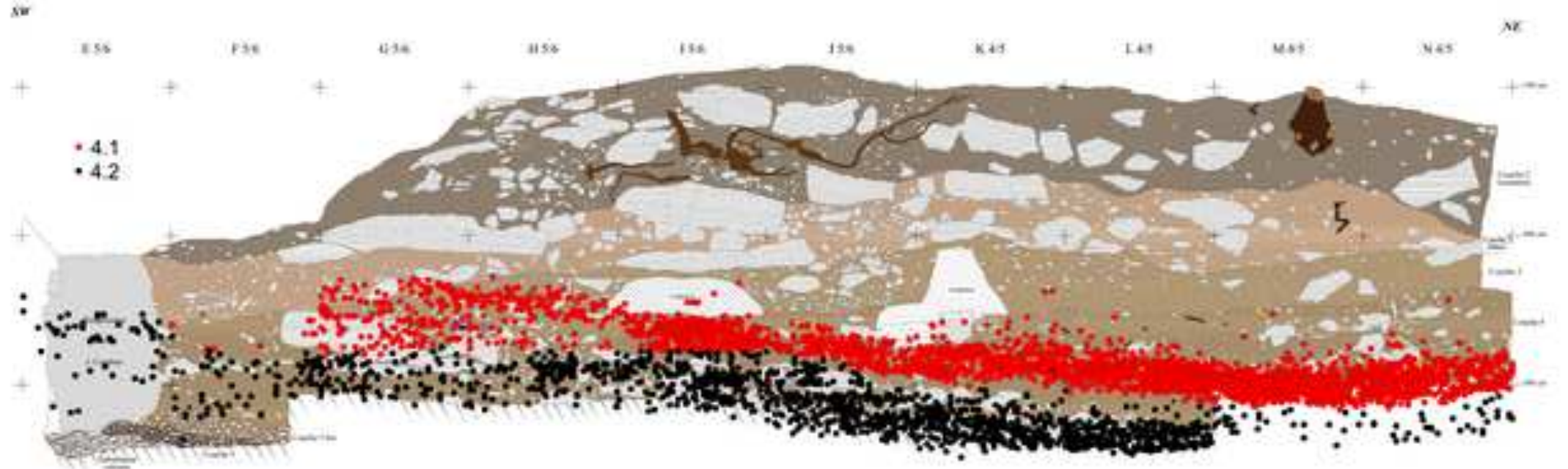


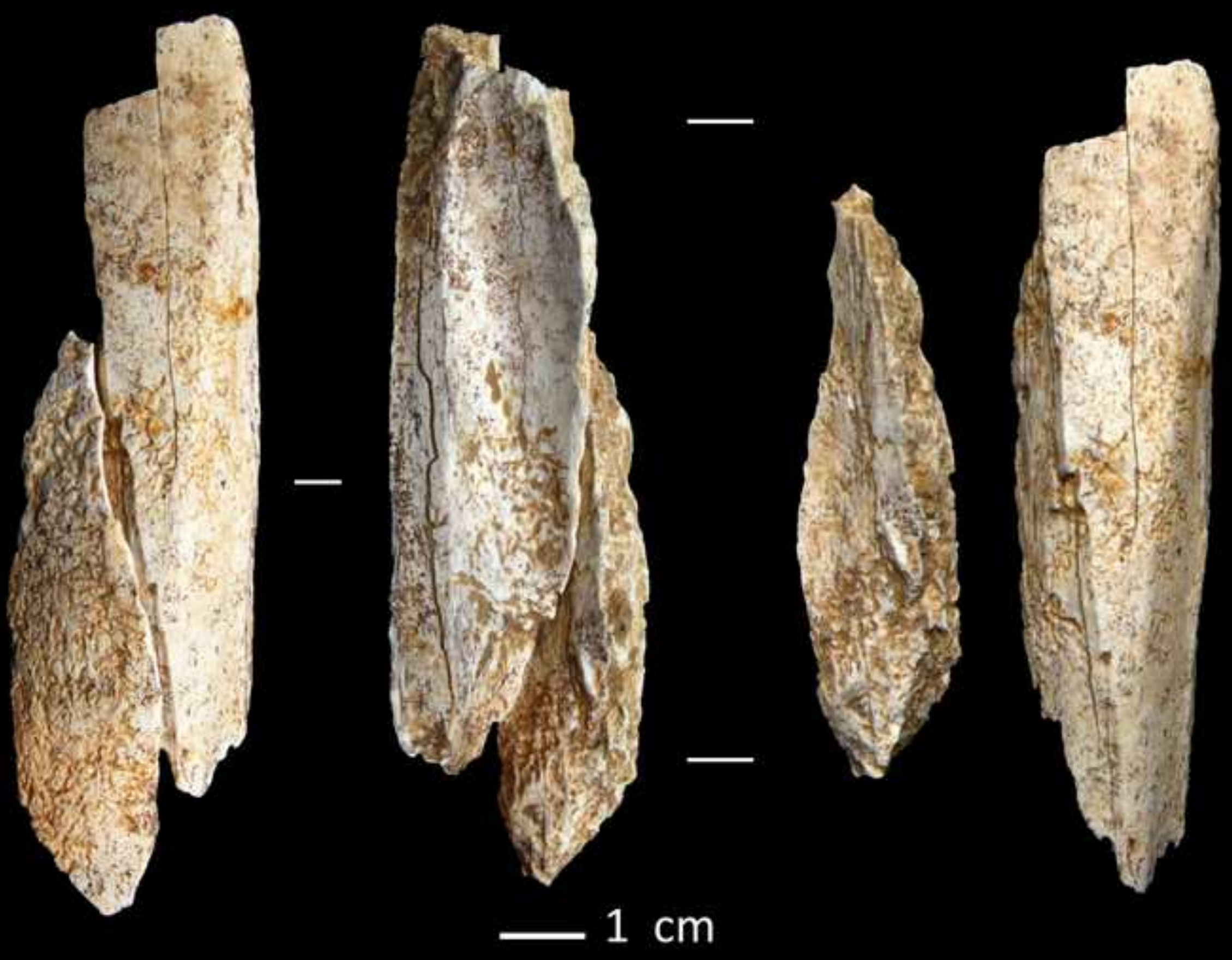




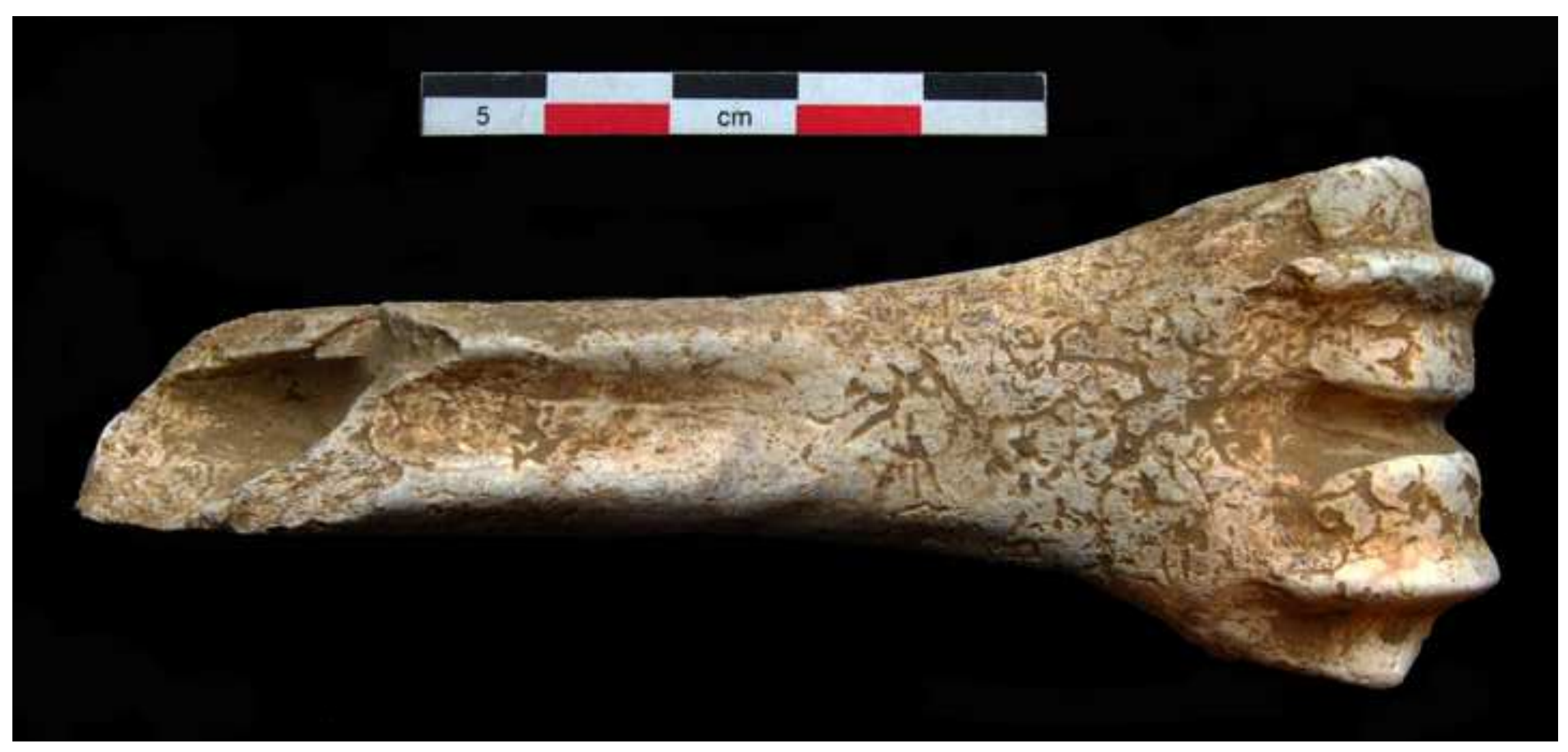




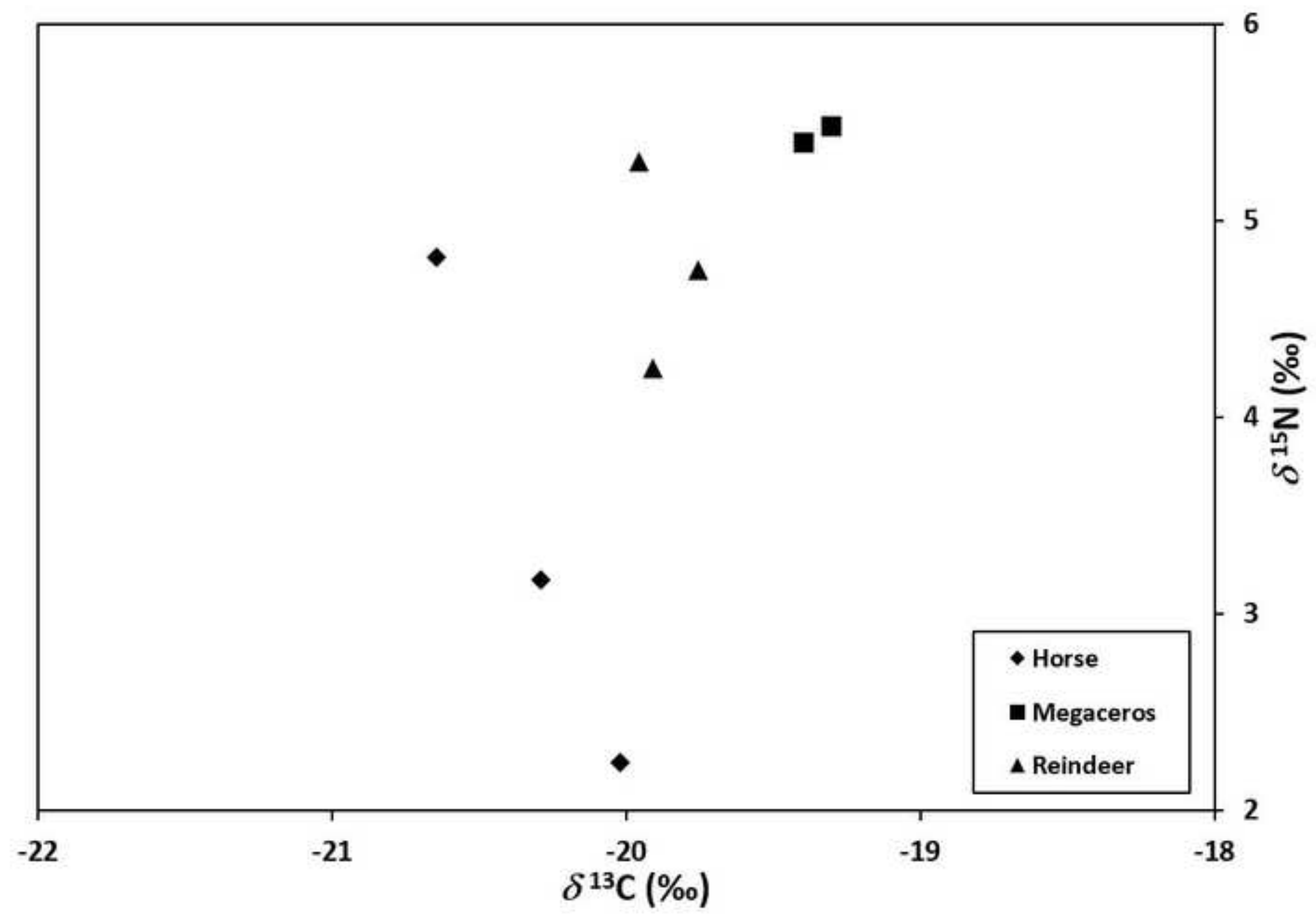




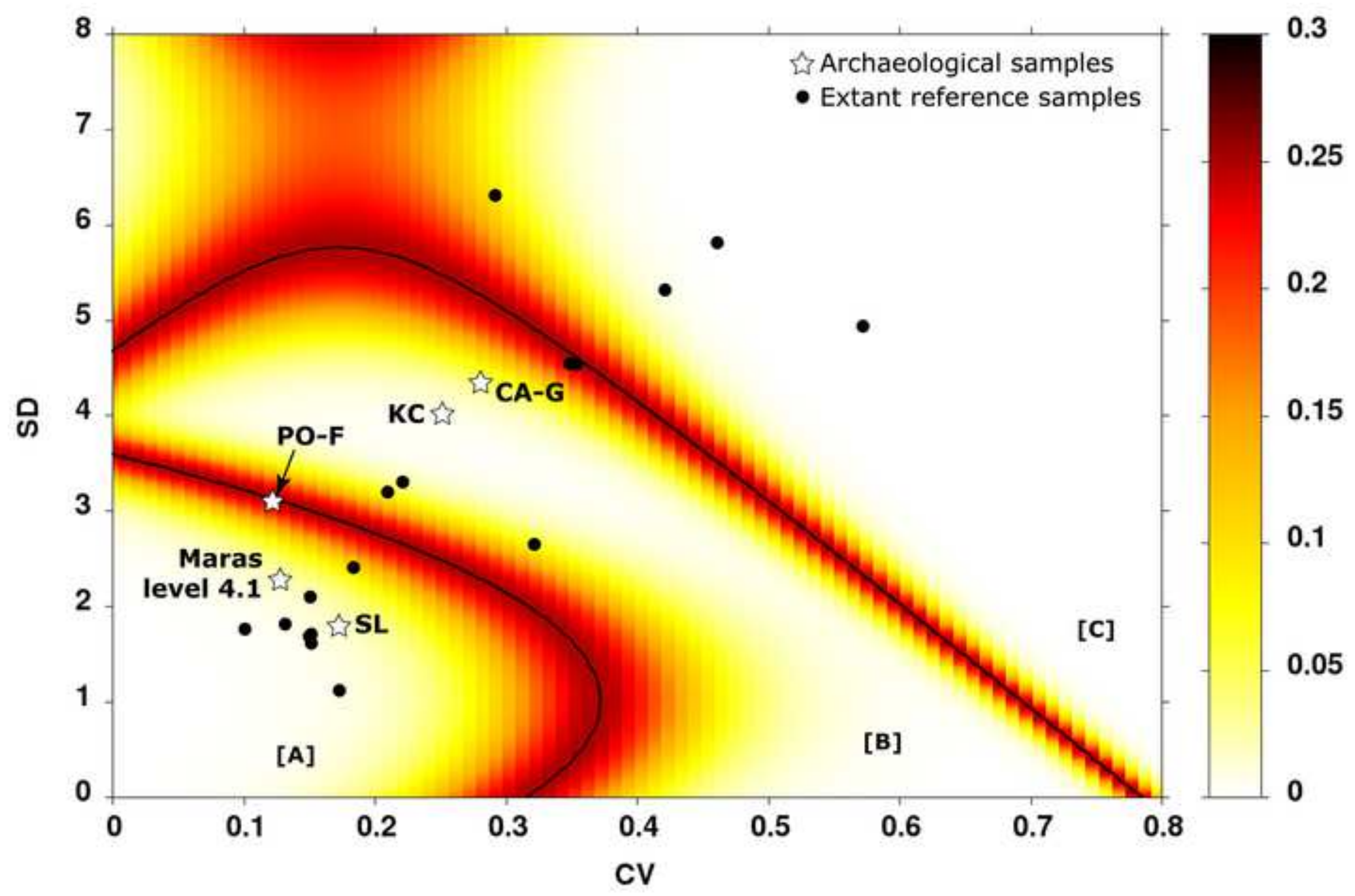




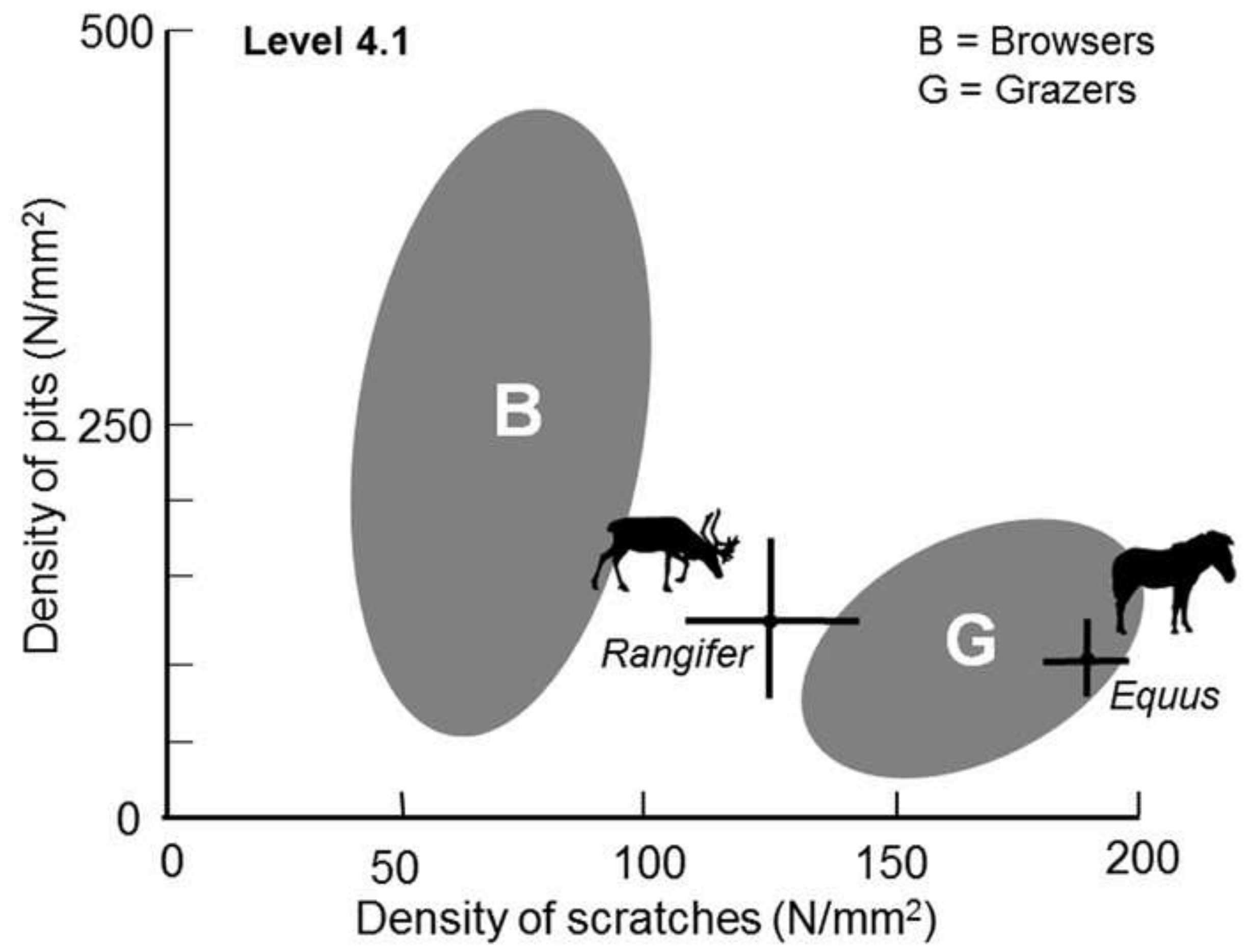


Figure 8.

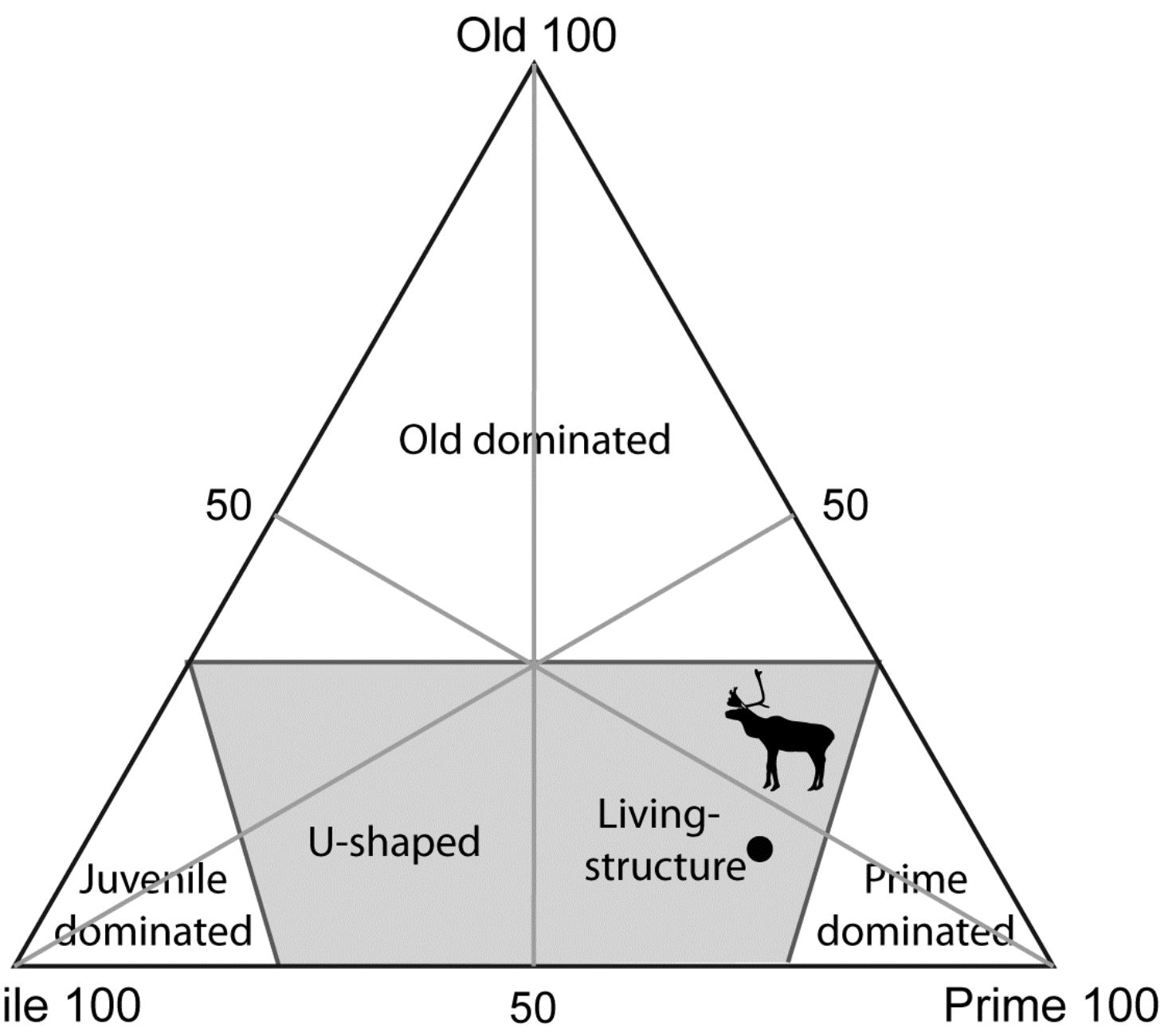

Juvenile 100

Prime 100 
Figure 9.

\section{Survival rates}

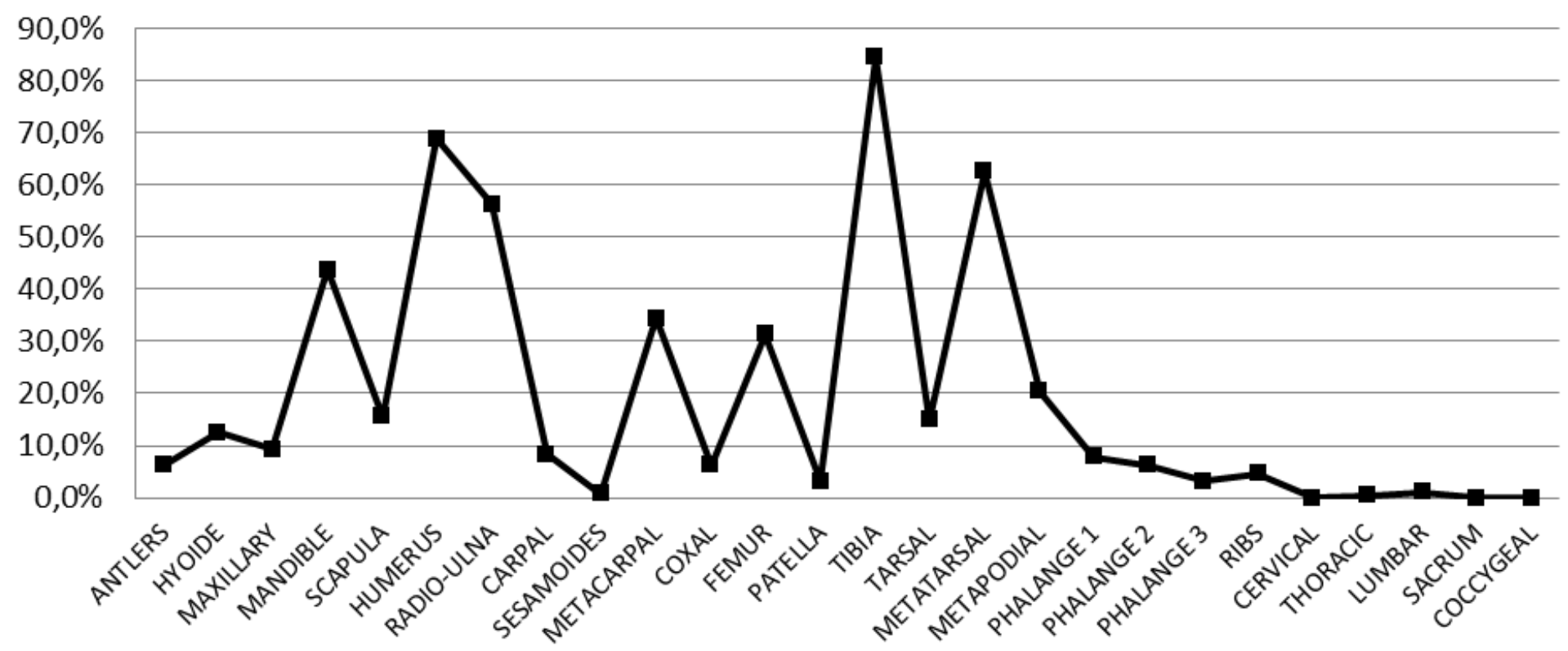




\section{Supplementary information.}

Article title: Neanderthal selective hunting of reindeer? The case study of Abri du Maras (southeastern France)

\section{Journal name: AAS}

Author names: Daujeard C.*, Vettese D., Britton K., Béarez P., Boulbes N., Crégut-Bonnoure E., Desclaux E., Lateur N., Pike-Tay A., Rivals F., Allué E., Chacón M.G., Courty M.-A., Gallotti R., Hardy B., Puaud S., Moncel M.-H.

Affiliation of the corresponding author: Histoire Naturelle de I'Homme Préhistorique (HNHP, UMR 7194), Sorbonne Universités, Muséum national d'Histoire naturelle (MNHN), CNRS, Université de Perpignan Via Domitia, Institut de Paléontologie Humaine, 1 rue René Panhard, 75013 Paris, France

E-mail address of the corresponding author: camille.daujeard@mnhn.fr

\section{$\underline{\text { SI Tables }}$}

Table S1. Burning damage categories based on colour (adapted from Stiner et al., 1995).

\begin{tabular}{l|l|l} 
Burnt stages & Descriptions & Colour \\
\hline 0 & Not burnt & Light cream \\
\hline 1 & Slightly burnt (localized and < half carbonized) & Brown \\
\hline 2 & Slightly burnt (> half carbonized) & Brown/Black \\
\hline 3 & Fully carbonized & Black \\
\hline 4 & Localized < half calcined & Black/Grey-White \\
\hline 5 & $>$ Half calcined & Grey-White \\
\hline 7 & Fully calcined & White \\
\hline & Highly calcined & White/Turquoise
\end{tabular}

Table S2. Number and percentage of recorded bone remains (NR=2718) with green, dry, frozen or indeterminate bone breakage.

\begin{tabular}{l|l|l|l|l|l|l|l|l} 
& \multicolumn{3}{|l|}{ Green } & \multicolumn{2}{l|}{ Dry } & Gelifracts & \multicolumn{2}{|l}{ Indeterminate } \\
\hline NR & NR & $\%$ & NR & $\%$ & NR & $\%$ & NR & $\%$ \\
\hline 2718 & 2003 & $73.69 \%$ & 950 & $34.95 \%$ & 58 & 2.13 & 483 & $17.77 \%$
\end{tabular}

Table S3. Climatic and edaphic alterations observed for coordinated bone remains (NR=2718).

\begin{tabular}{l|l|l|l|l} 
fissuration & 0 & 1 & 2 & 3 \\
\hline NR & 2027 & 675 & 144 & 11 \\
\hline$\%$ & 70.9 & 23.6 & 5.0 & 0.4 \\
\hline desquamation & 0 & 1 & 2 & 3 \\
\hline NR & 1024 & 601 & 620 & 612 \\
\hline$\%$ & 35.8 & 21.0 & 21.7 & 21.4 \\
\hline polish & 0 & 1 & 2 & 3 \\
\hline NR & 2639 & 168 & 45 & 5 \\
\hline$\%$ & 92.4 & 5.9 & 1.6 & 0.2 \\
\hline concretions & 0 & 1 & 2 & 3
\end{tabular}




\begin{tabular}{l|l|l|l|l}
$\mathrm{NR}$ & 2632 & 188 & 34 & 3 \\
\hline$\%$ & 92.1 & 6.6 & 1.2 & 0.1 \\
\hline corrosion & 0 & 1 & 2 & 3 \\
\hline $\mathrm{NR}$ & 248 & 1228 & 718 & 663 \\
\hline$\%$ & 8.7 & 43.0 & 25.1 & 23.2 \\
\hline root etchings & 0 & 1 & 2 & 3 \\
\hline NR & 291 & 1082 & 780 & 704 \\
\hline$\%$ & 10.2 & 37.9 & 27.3 & 24.6 \\
\hline black colorations & 0 & 1 & 2 & 3 \\
\hline NR & 984 & 1401 & 432 & 40 \\
\hline$\%$ & 34.4 & 49.0 & 15.1 & 1.4 \\
\hline red/orange colorations & 0 & 1 & 2 & 3 \\
\hline NR & 534 & 489 & 30 & 0 \\
\hline$\%$ & 50.7 & 46.4 & 2.8 & 0.0
\end{tabular}

Table S4. Fish remains from level 4.1.

\begin{tabular}{l|l|l|l|l|l|l}
$\mathrm{m}^{2}$ & Family & Species & Element & NISP & MNI & $\begin{array}{l}\text { Estimated } \\
\text { weight (g) }\end{array}$ \\
\hline $\mathrm{H}-6$ & Cyprinidae & unidentified & vertebrae + rib & 5 & 1 & 750 \\
\hline $\mathrm{I}-6$ & Cyprinidae & Squalius cephalus & $\begin{array}{l}\text { vertebrae }+ \\
\text { pharyngeal bone }\end{array}$ & 12 & 1 & 700 \\
\hline $\mathrm{I}-6$ & Cyprinidae & unidentified & $\begin{array}{l}\text { vertebrae }+ \text { rib }+ \\
\text { parasphenoid }\end{array}$ & 16 & 2 & $550-850$ \\
\hline $\mathrm{J}-6$ & Cyprinidae & unidentified & vertebra & 1 & 1 & 600 \\
\hline I-6 & Percidae & Perca fluviatilis & scales & 12 & & \\
\hline Unidentified fish & & fragments & 121 & &
\end{tabular}

Table S5. Cementochronology results (all lower teeth unless indicated; rt.: right; lft.: left).

\begin{tabular}{|c|c|c|c|c|c|}
\hline $\begin{array}{l}\text { Specimen \#, } \\
\text { context, } \\
\text { description }\end{array}$ & $\begin{array}{l}\text { Tooth } \\
\text { (Side) }\end{array}$ & Species & \# Annuli, Zone state of completion & Magnification & $\begin{array}{l}\text { Estimated } \\
\text { season of death }\end{array}$ \\
\hline $\begin{array}{l}\text { (1) } \\
\text { L6 } 142 \text { et } 28\end{array}$ & M1 rt. & Rangifer & $\begin{array}{l}\text { 4+ annulli, last } 4 \text { annuli visible; } \\
\text { earlier ones too mineralized to } \\
\text { count } \\
F=\text { nearly complete zone }\end{array}$ & $100 x$ & autumn \\
\hline $\begin{array}{l}(2) \\
\text { M6 } 338\end{array}$ & P4 lft. & Rangifer & $\begin{array}{l}\text { 4-5 annuli visible } \\
F=\text { complete zone }\end{array}$ & $\begin{array}{l}100 x \\
\text { with lambda } \\
\text { plate }\end{array}$ & $\begin{array}{l}\text { autumn/late } \\
\text { autumn }\end{array}$ \\
\hline $\begin{array}{l}\text { (3) } \\
\text { J6 } 67\end{array}$ & P2 Ift. & Rangifer & $\begin{array}{l}2 \text { or } 3 \text { annuli visible } \\
\mathrm{F}=\text { in growth zone, but too } \\
\text { mineralized to assess season }\end{array}$ & $100 x$ & $\begin{array}{l}\text { too } \\
\text { mineralized, no } \\
\text { determination } \\
\end{array}$ \\
\hline $\begin{array}{l}\text { (4) } \\
\text { M6 } 235\end{array}$ & $\begin{array}{l}\text { M3 rt. } \\
\text { (upper) }\end{array}$ & Rangifer & too mineralized, no determination & & $\begin{array}{l}\text { too } \\
\text { mineralized, no } \\
\text { determination }\end{array}$ \\
\hline $\begin{array}{l}\text { (5) } \\
\text { H7 } 84\end{array}$ & $\begin{array}{l}\text { M3 rt. } \\
\text { (upper) }\end{array}$ & Megaloceros & too mineralized, no determination & & $\begin{array}{l}\text { too } \\
\text { mineralized, no } \\
\text { determination }\end{array}$ \\
\hline $\begin{array}{l}\text { (6) } \\
\text { N6 } 178\end{array}$ & P2 Ift. & Rangifer & $\begin{array}{l}6+\text { annuli } \\
F=\text { edge too degraded to assess } \\
\text { seasonality }\end{array}$ & $40 x$ & $\begin{array}{l}\text { too } \\
\text { mineralized, no } \\
\text { determination }\end{array}$ \\
\hline
\end{tabular}




\begin{tabular}{l|l|l|l|l|l}
$\begin{array}{l}\text { (7) } \\
\text { M6 671 }\end{array}$ & $\begin{array}{l}\text { P4-M1 } \\
\text { rt. }\end{array}$ & Rangifer & $\begin{array}{l}\text { 3 annuli visible } \\
\text { F= in growth zone 3/4 complete } \\
\text { only final } 2 \text { annuli visible } \\
\text { F= in growth zone 3/4 complete }\end{array}$ & 100x & autumn \\
\hline $\begin{array}{l}\text { (8) } 126 \\
\text { H6 } 126\end{array}$ & M1 lft. & Rangifer & No cementum, not analyzed & & \\
\hline M6 520 & M2 lft. & Rangifer & $\begin{array}{l}\text { ca. } 5 \text { annuli } \\
\text { F= nearly complete growth zone }\end{array}$ & 100x & $\begin{array}{l}\text { autumn/late } \\
\text { autumn }\end{array}$
\end{tabular}

Table S6. Characteristics of burnt elements.

\begin{tabular}{l|l|l|l|l|l|l|l|l|l|l|l} 
& $\mathrm{c1}$ & $\mathrm{c} 2$ & $\mathrm{c3}$ & $\mathrm{c4}$ & $\mathrm{c5}$ & $\mathrm{c6}$ & $\mathrm{c7}$ & total & $\%$ & $\mathrm{NR}$ & $\%$ \\
\hline spongiosa 0-25 mm & & 75 & 309 & 80 & 42 & 14 & 1 & 521 & $22.6 \%$ & 1890 & $27.6 \%$ \\
\hline compacta 0-25 mm & 11 & 318 & 1008 & 214 & 83 & 30 & 14 & 1678 & $72.8 \%$ & 6503 & $25.8 \%$ \\
\hline spongiosa 26-50 & & 1 & 4 & 6 & 4 & & & 15 & $0.7 \%$ & 320 & $4.7 \%$ \\
\hline compacta 26-50 & 4 & 8 & 12 & 11 & 1 & 1 & & 37 & $1.6 \%$ & 1129 & $3.3 \%$ \\
\hline comp-spong > 50 & 1 & 4 & 1 & & & & & 6 & $0.3 \%$ & 1050 & $0.6 \%$ \\
\hline isolated teeth & & 6 & 21 & 8 & 9 & 3 & 2 & 49 & $2.1 \%$ & 231 & $21.2 \%$ \\
\hline total & 16 & 412 & 1355 & 319 & 139 & 48 & 17 & 2306 & $100.0 \%$ & 11123 & $20.7 \%$ \\
\hline at least carbonized (c3 to c7) & & & & & & & & 1878 & $81.5 \%$ & & \\
\hline at least calcined (c4 to c7) & & & & & & & & 523 & $22.7 \%$ & & \\
\hline burnt elements < 25 mm & & & & & & & & 2199 & $95.4 \%$ & & \\
\hline spongious elements (c3 to c7) & & & & & & & & 460 & $24.5 \%$ & &
\end{tabular}




\section{SI Figures}

Figure S1. Summarized data concerning the aeolian silt sediments in layer 4. a). Calcimetry: measuring the average calcium carbonate content ( $\mathrm{CaCO} 3)$. b). Grain-size: sediment texture is silty to sandy-silty. c). Microphotographs of micromorphological features of sediment in layer 4: bottom; sandy silt with some coarse sand. Porosity is well-developed, calcium carbonate impregnated the sediment around the pores. Voids and coatings are related to root development. Middle; limestone fragment from the frost-shattering of the shelter wall. Perforations are due to the activity of endolithic lichens. Top; Calcitic biospheroid produced by earthworms (Lumbricidae).

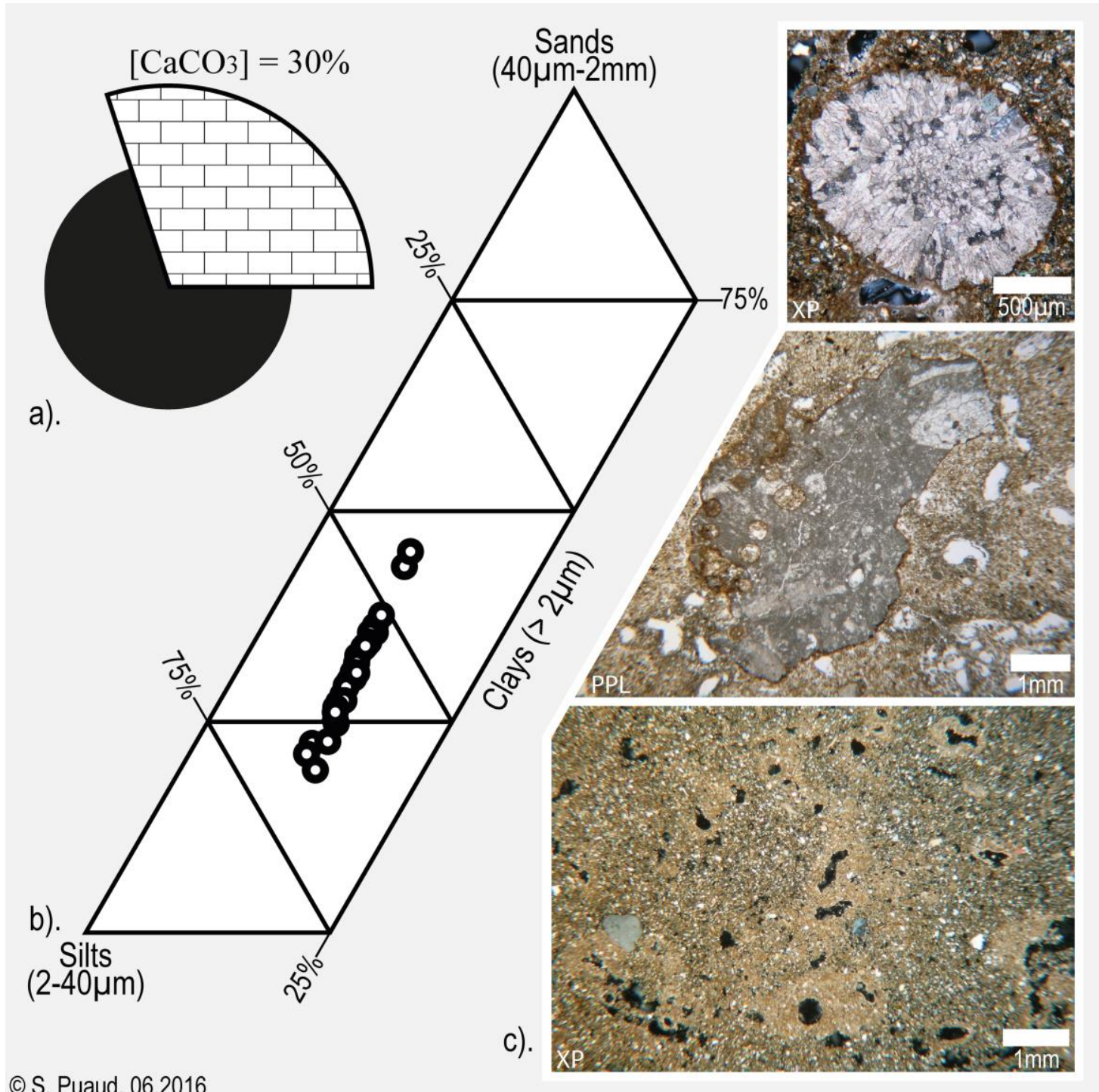


Figure S2. Distribution of bone fragments by size classes (intervals: 0-25 mm).

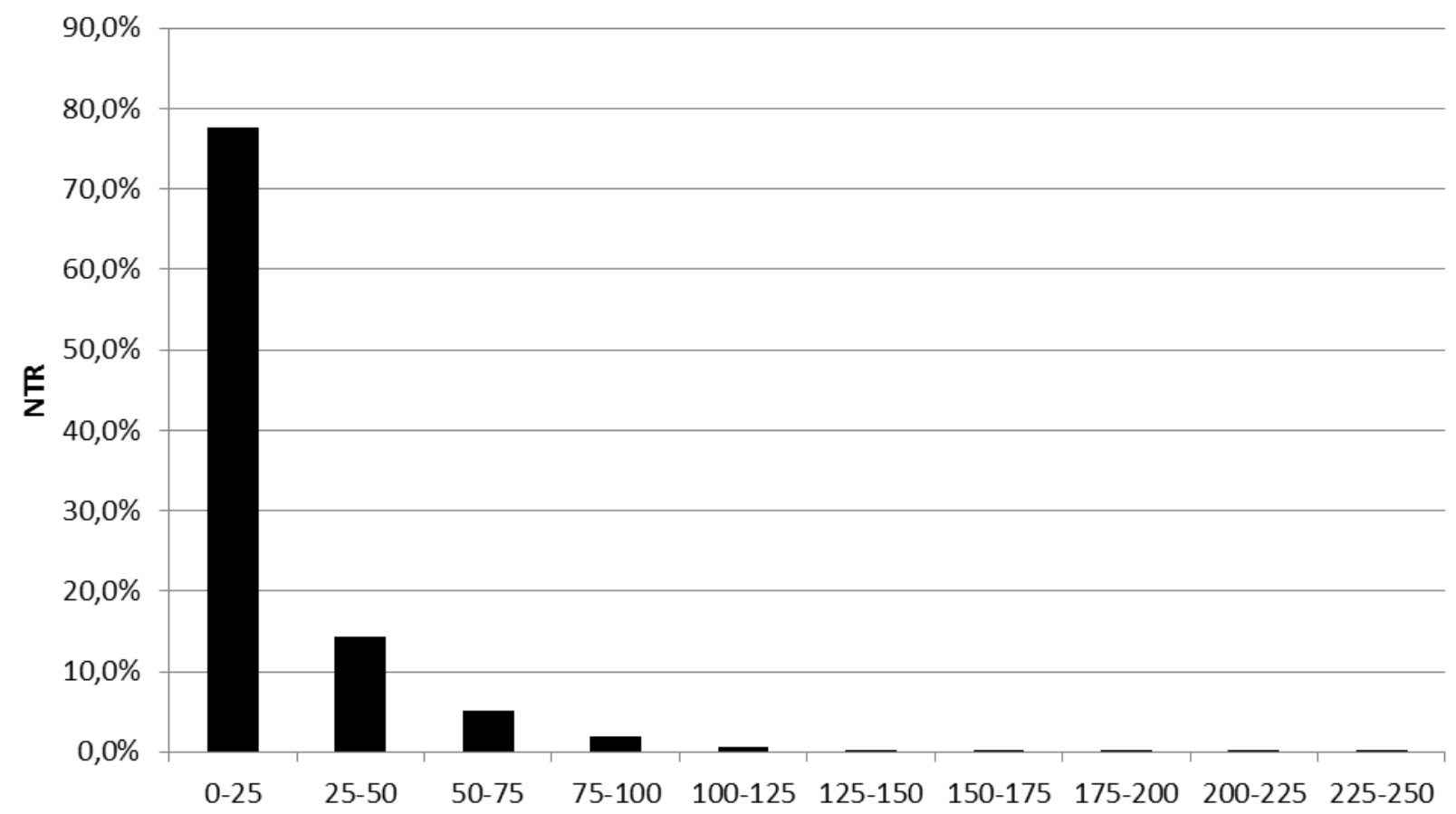

Figure S3. \%MAU of the different reindeer long bone portions.

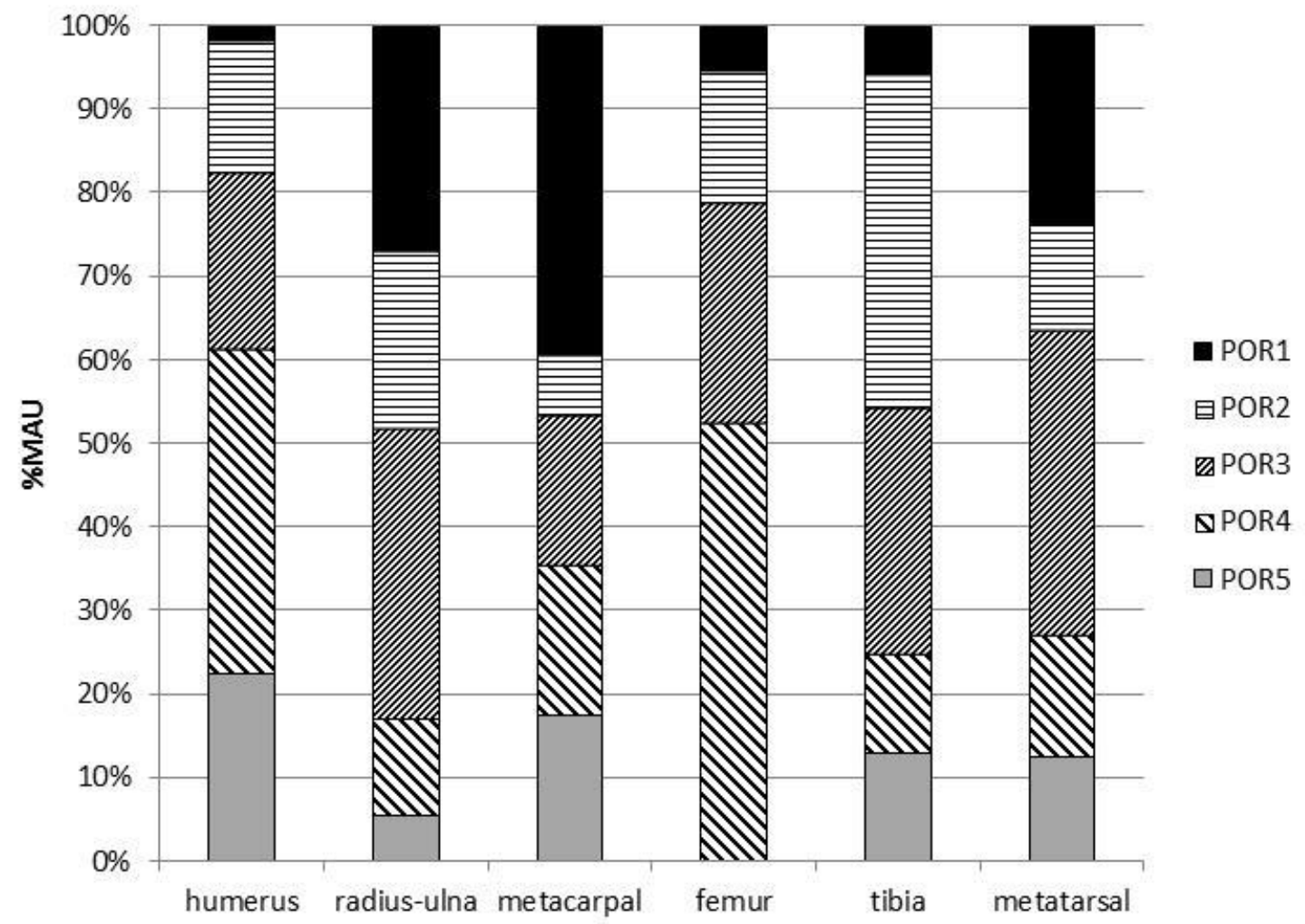


Figure S4. Three-dimensional bar diagram showing relative frequencies of shaft length and circumference (NR=1656).

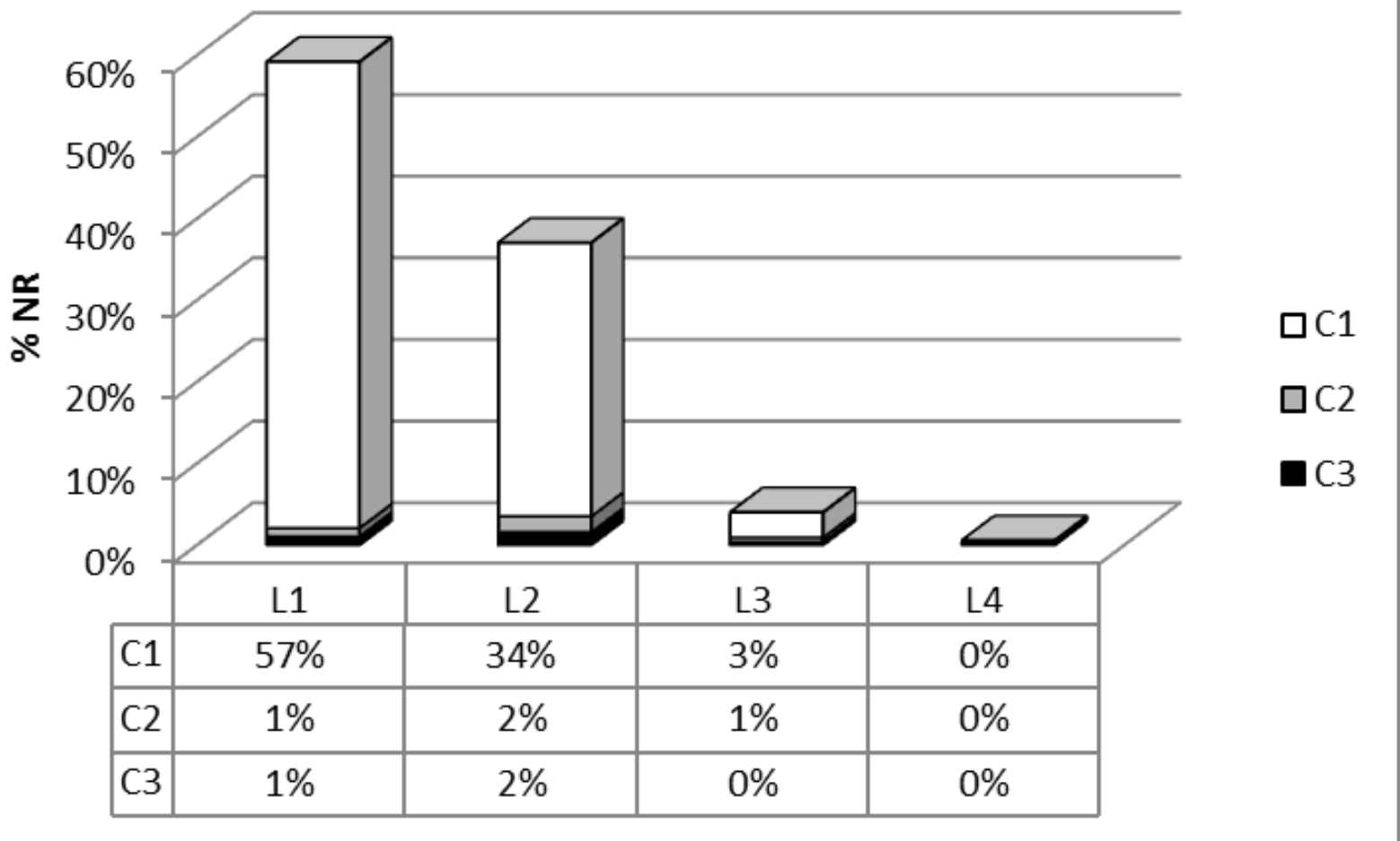

Figure S5. Distribution of the skeletal elements for reindeer according to the seven carcass pieces (\%MAU).

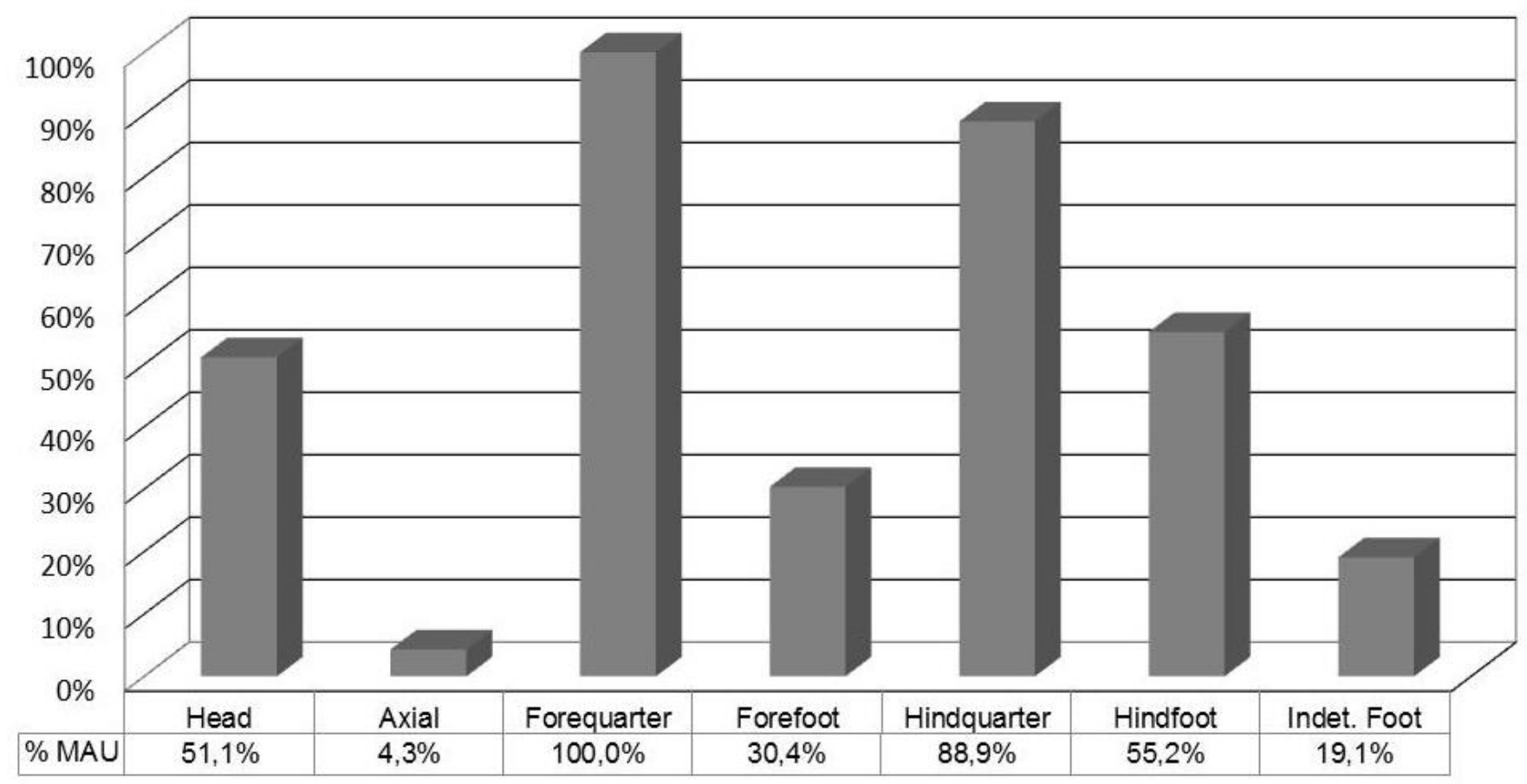

